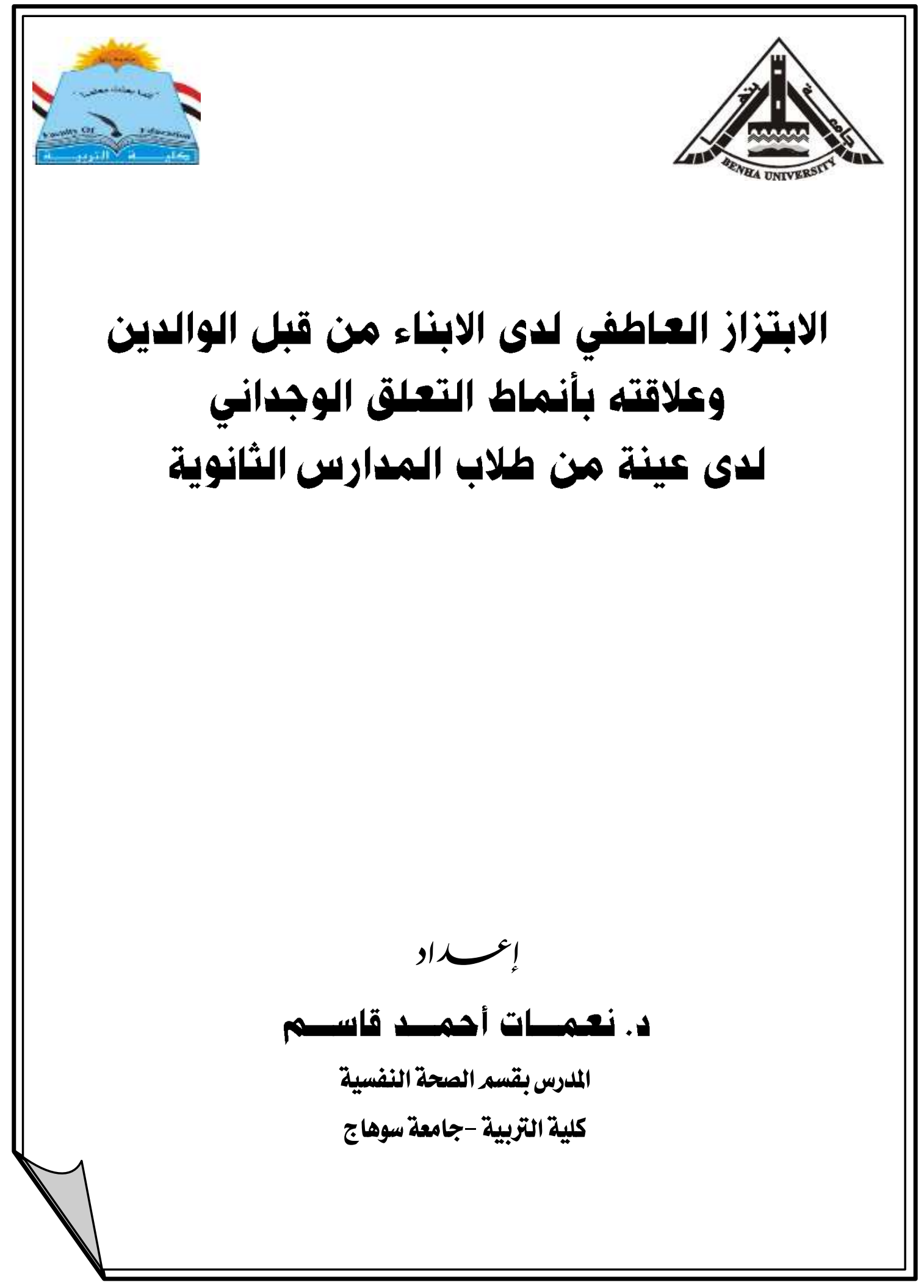




\section{الابتزاز العاطفي للى الابناء من قبل الواللين وعلاقته بأنماط التعلق الوجداني للى عينة من طلاب المدارس الثانوية}

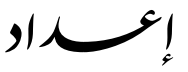

ه. نعسمات أحمد قاسميم

المدرس بقسم الصحة النفسية

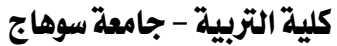

\section{المستخلـص}

هدف البحث الحالي إلى التعرف على الابتزاز العاطفى بأبعاده الثثلثة ( الخوف، الالزام ،

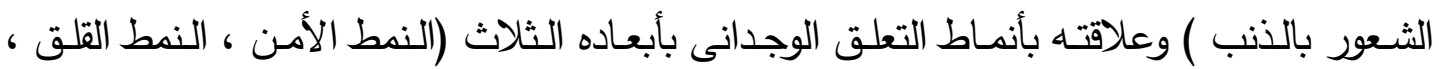
النمط التجنبى ) وعلاقته ببعض المتغيـرات الديموغرافيـة ( النـوع - المستوى التعليمي للوالدين)

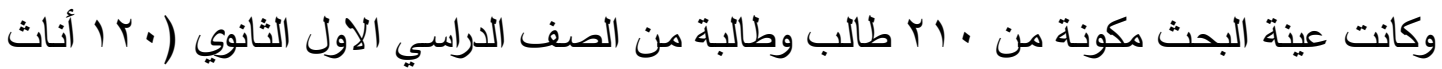
، .9 ذكور) أعمارهم ما بين (10-10 سنة) طبقت عليهم مقياس الابتزاز العاطفى إعداد الباحثة

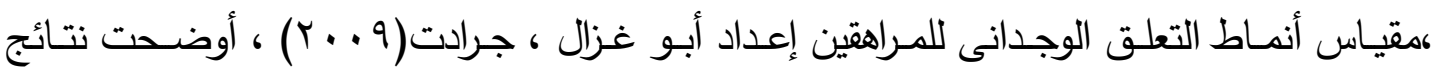

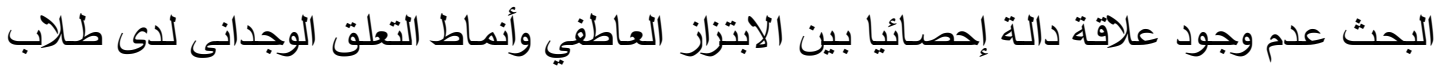

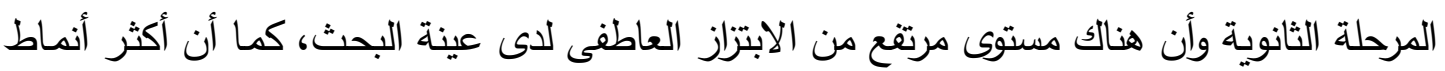

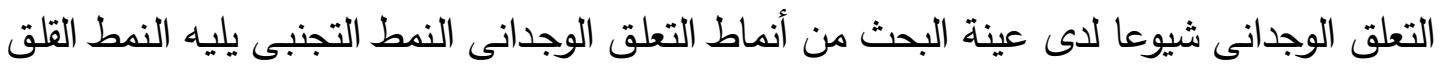

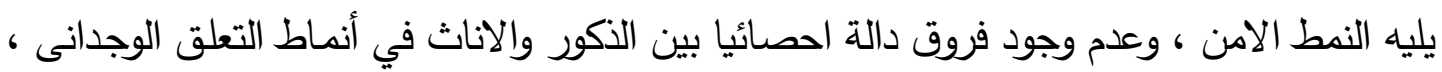
ويوجد فروق دالة احصائيا بين الذكور والاناث في مستوى الابتزاز العاطفى لصالح الاناث، ولئ ورجود فروق دالة احصائيا للى عينة البحث في مستوى الابتزاز العاطفى تعزى إلى الدستوى التعليمي

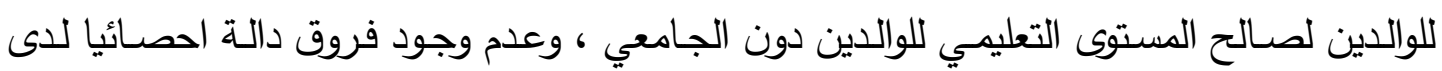
عينة البحث في أنماط التعلق الوجدانى تعزى إلى المستوى التعليمي للوالدين. الكلمــات المفتاحيــة: الابتزاز العاطفي - أنماط التعلق الوجدانى - طلاب المرحلة الثانوية. 
د/ نعمات قاسم الابتزاز العاطفي لوى الابناء من قبل الوالدين وعلاقته بأنماط التعلةع الوجداني لدى عينة من الطلاب المدراس الثانوية

\section{A Strategy Based on Successful Intelligence Theory to Develop linguistic Fluency Skills for Preparatory Stage Pupils}

\section{Abstract}

The present study aimed to identify emotional blackmail in its three dimensions (fear, obligation, and guilt) and its relationship to emotional patterns in its three dimensions (safe mode, anxiety mode, avoidance pattern) and its relationship to some demographic variables (gender - the educational level of parents). The research sample consisted of 210 students in the first class of secondary school (120 females, 90 males). Their age (15-17 years old). The researcher prepared an emotional blackmail scale and applied the measurement of emotional attachment patterns for adolescents, prepared by Abu Ghazal, Gradat, (2009),. The results showed the followings: There is no a statistically significant relationship between emotional blackmail and emotional attachment patterns among high school students and there is a high level of emotional blackmail among the sample of students, the most common emotional patterns are the avoided pattern, followed by the anxiety pattern, then the safe pattern, no statistically significant differences between males and females in emotional patterns, there is a statistically significant differences between males and females in the level of emotional blackmail in favor of females, there are statistically significant differences in the level of emotional blackmail due to the educational level of parents in favor of without a university level, and no statistically significant differences in emotional patterns due to the educational level of the parents. 


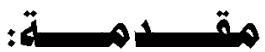

يسعى الانسـان باجتهاد موصـول نحو الثـعور والاحسـاس بالسـادة فهي غايـة حياتـه المرجوة في زمـن تعاظمـت فيـه تحديات الانسـان ومشكلاته، فالتغيرات في الجوانب الثقافيـة والاجتماعية والاسرية تلقى بظلالها على تفكير الانسان وتخطيطه لجوانب حياته ومن أكثر هذه المشكلات المشكلات الأسرية التي تتعلق بأساليب المعاملة الوالدية السوية أو الغير سوية مع الابناء خاصـة المراهقين والمراهقات في المرحلة الثانوية. ومـن أشكال الاسـاءة الانفعاليـة التي يتعـرض لهـا المراهقون وهـو شكل مـن أشكال الاستغلال الا وهو الابتزاز العاطفي للأبناء من قبل الوالدين سواء الاب أو الام هذا المصطلح يعتبر جديد على أذانتا وكذلك على دراسـات النفسية في الآونـة الاخيرة على حد علم الباحثة حيث ظهر بظهور كتاب عن الابتزاز العـاطفي لسوزان فورورد (99v ( ) الذى يتطرق إلى مكونات الابتزاز العاطفي ووسائله وكيفيه التصدي له. ويعتبر الابتزاز العـاطفي الذى يقوم بـه الاشـخاص المقربـون بتهديدنا (سـواء بطريقـة مباشرة أو غير مباشرة) بأنهم سوف يعاقبوننا اذا لم نفعل ما يريدونهه من أسلوب من الاساليب الغير سوية في العلاقات الاجتماعية سواء من قبل الاباء تجاه أبناءهم مثل دراسة محيى الدين ( • ( r) التي تناولت علاقة الابتزاز والمناخ الاسرى وبعض المتغيرات الشخصية لدى طالبات المرحلة الثانوية أو من قبل الزوج تجاه الزوجة مثل دراسة محمد (7 ا ـ ب) التي تتاولت الابتزاز العـاطفي مـن قبـل الزوج تجـاه الزوج وعلاقته بـأعراض الشخصية الحديـة، وكذلك هناك نوع اخــرمن الابتــزاز يتعـرض لـــه العمــلاء والمســتهلكين لأى ســلعة مثـل دراســـة ليــونج (Laung, A, 2005) والابتزاز العاطفي شكل من أشكال العنف والعدوان الذى لـ يعاقب عليه القانون، وإن كانوا لا يفصحون عنها وفى مثل هذا تصبح قوة تحد من قدرة الفرد على استقراره واتزانه وتتتج هذه الاعتداءات عن تدمير نفسى لا واع عن طريق تصرفات عدوانية واضحة أو مخفية يقوم بها المبتز ازاء الضحية، فمن الممكن ان تكون عبر السكوت أو التلميح أو كلمات غير مؤذية ظاهريا الا انها في الواقع قادرة على ان تزعزع انسانا أو تأنبه وهكذا يستطيع المبتز أن يسيطر

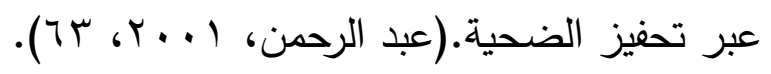


وهنالك طرق متعددة وأشكال متنوعة من الابتزاز يتعرض لها أفراد الهجمع بأسره سواء

في الاسرة او خارجه، ولكن في البحث الحالى تركز الباحثة على الابتزاز العاطفي التي يتعرض له المراهقون من قبل الوالدين الذين يتسمون بسمات وخصائص انفعالية منها الحساسية الزائدة

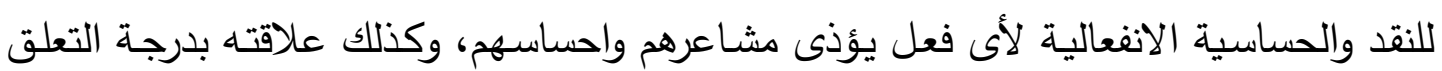

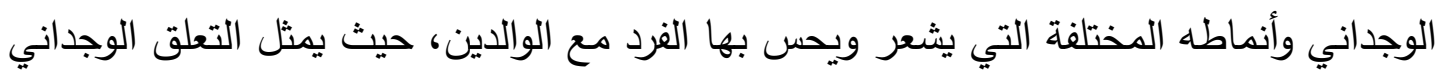

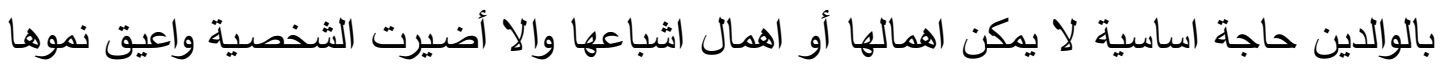
فالأطفال يولدون ولديهم الحاجة للحب والامن واقامة علاقات حميمة وامنة مع والديهم يمدونهم

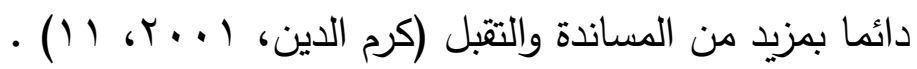

منذ أن خلق الله سبحانه وتعالى الإنسان، وهو يعيش وسط مجتــع تحكمـه الطبيعة

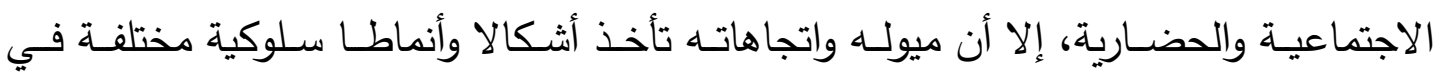

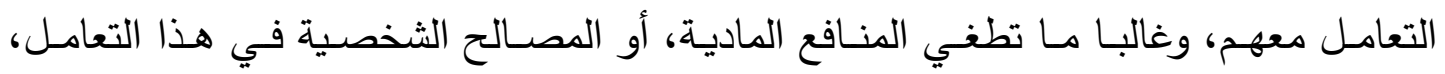

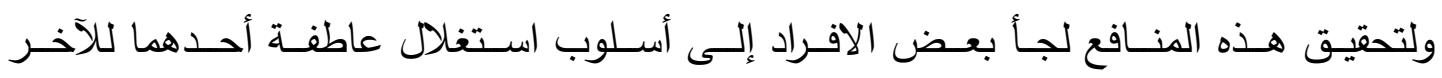

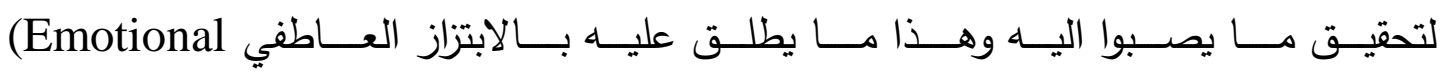
(Blackmail،

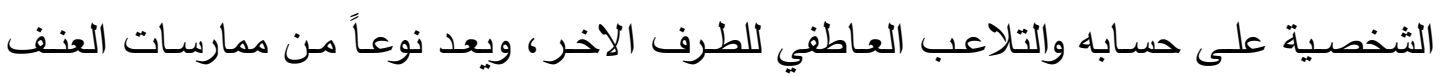

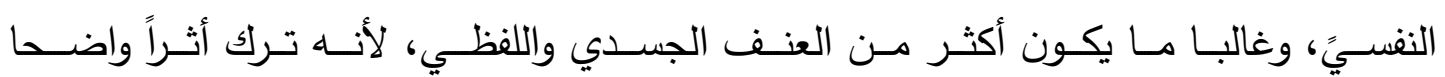

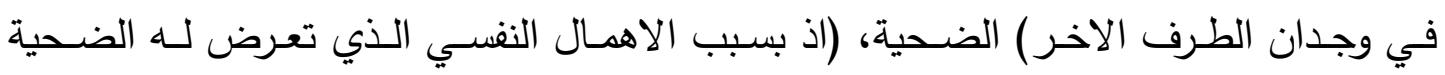

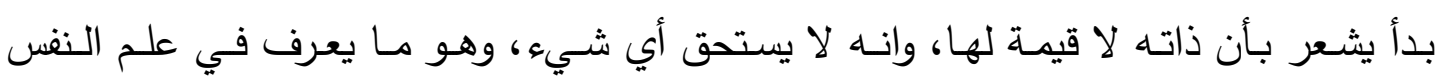

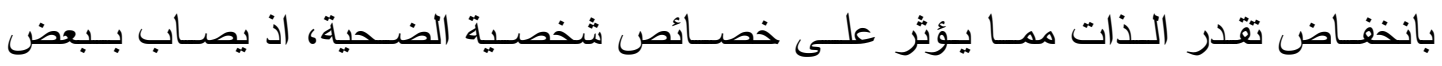

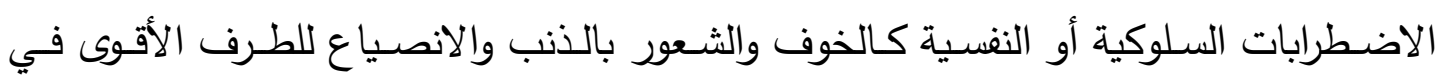

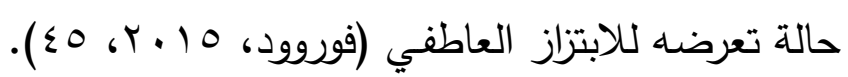

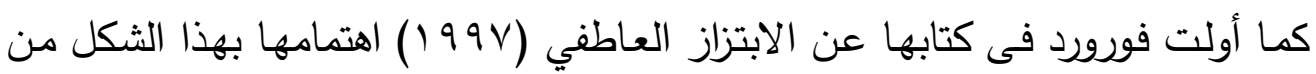

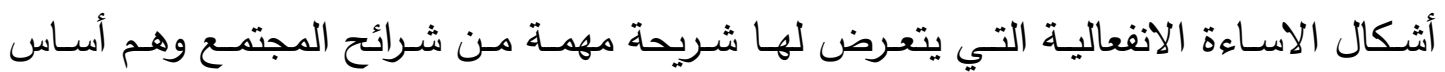

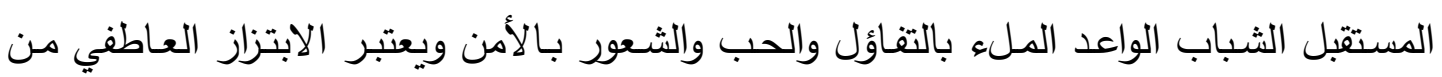


المصطلحات الحديثة على التراث النفسي العربي على حد علم الباحثة ممـا زاد من اهتمام الباحثة على الاطلاع للمزيد من الدراسات التي تناولته وأولت له بالدراسة ووجدت البـات الباحثة ندرة

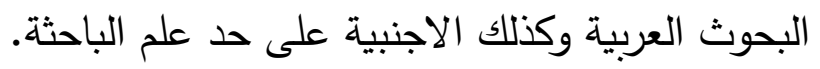

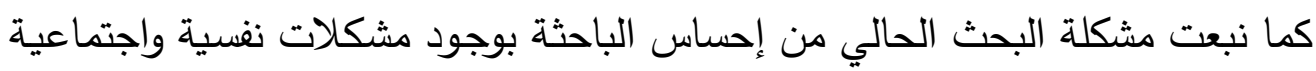

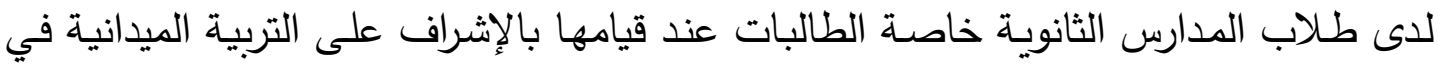

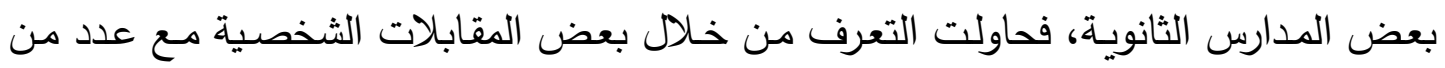

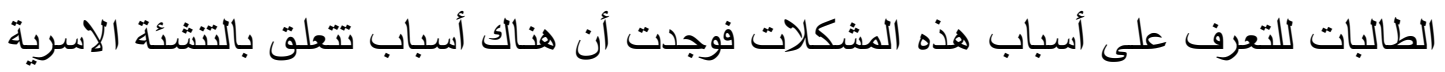

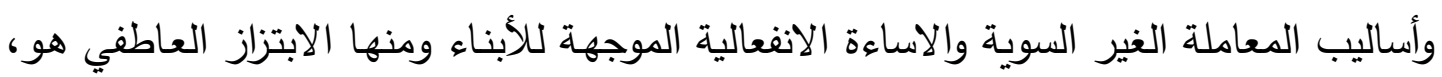

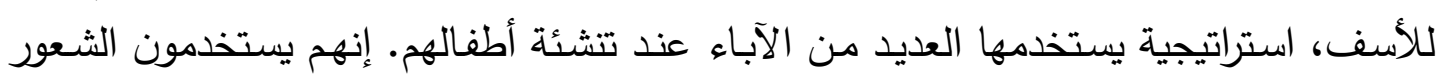

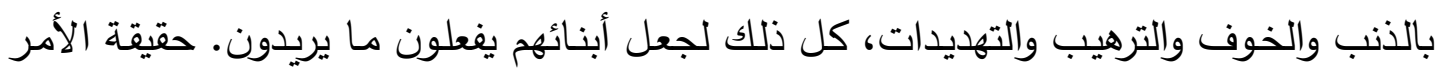

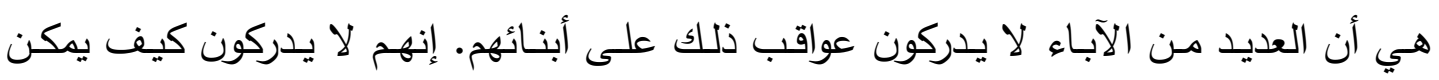
لأساليبهم الغير سوية أن تؤثر على العلاقة التي تربطهم بها.

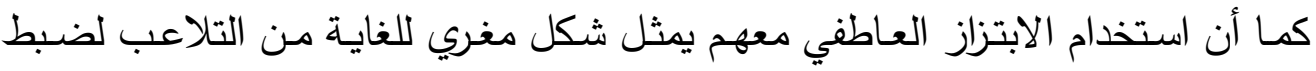

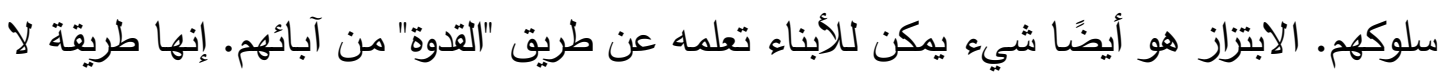
نختارها عادة بوعي. ومع ذلك، عندما نرى مدى فعاليتها، فإننا نقرر الاستمرار في استخدامها.

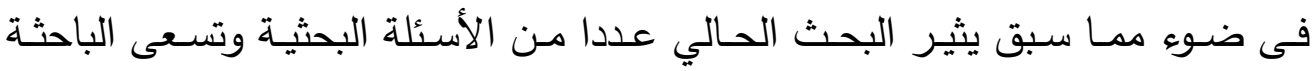

$$
\text { للإجابة عنها من خلال إجراءات البحث: }
$$

1- هل هناك علاقة ذات دلالة احصائية بين الابتزاز العاطفي وأنماط التعلق الوجداني لدى

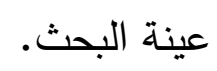

r- ما مستوى الابتزاز العاطفي لاى عينة البحث؟

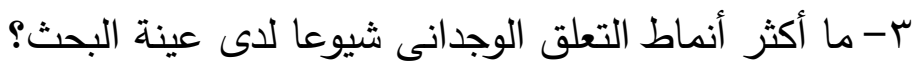
ع- هل توجد فروق بين الجنسين (الذكور والاناث) في مستوى الابتزاز العاطفي. ه- هل توجد فروق بين الجنسين (الذكور والاناث في مقياس انماط التعلق الوجداني.

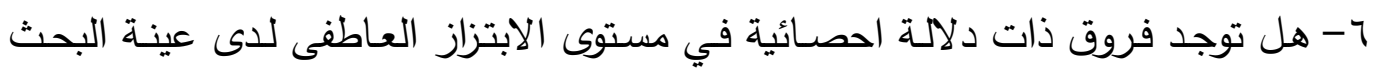

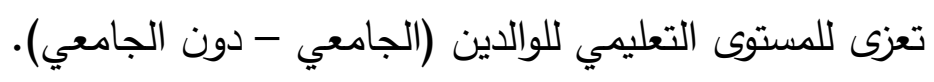

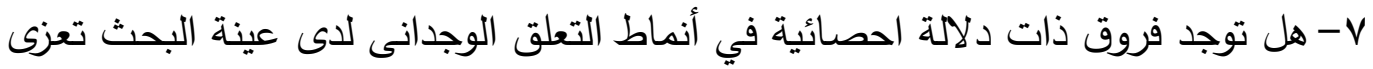
للمستوى التعليمي للوالدين (الجامعي - دون الجامعي). 


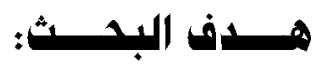

هدف البحث الحالي إلى التعرف على العلاقـة بين الابتزاز العاطفي وأنماط التعلق الوجداني لدى طلاب المرحلة الثانوية والتعرف على مستوى الابتزاز العاطفي للى عينة البحث والتعرف على أثر بعض المتغيرات الديموغرافية على نتائج الدراسـة ومنها (الجنس - المستوى التراري التعليمي والاجتماعي للوالدين).

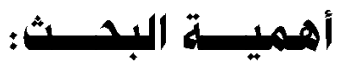

تأتى أهمية البحث من خلال النقاط الاتية: ا- أهمية المرحلة التي تطبق عليها الدراسة الحالية وهم طلاب المرحلة الثانويـة التي تتحدد فيها مستقبلهم المهني ويبدأ فيها مرحلة العطاء للمجتمع. ץ- تتمثل أهمية البحث الحالي في محاول إلقاء الضوء على مفهوم الابتزاز العاطفي وجوانبه المتعددة ومحاولة توضيح هذا المفهوم الثرى والذي لم يتم تداوله على مستوى موسع على حد علم الباحثة مما يعد إثراء للعديد من الاراسات المستقبلية فى مجال الصحة النفسية. ب- تتمثل أهميـة البحث الحالي في اعداد مقياس الابتزاز الانفعـالى يستفيد منـه الباحثين والعاملين فى مجال الصحة النفسية والذي يمثل وسيلة يمكن فى ضوئه تصميم العديد من البرامج الإرشادية في خفض الابتزاز الانفعالى فضـلا عن استخدامه فى أغراض التشخيص والتّريب فى العلاج. ع - ندرة البحوث العربية التي تناولت العلاقة بين الابتزاز العاطفي وأنماط التعلق الوجداني فهذه الدراسة تعتبر اثراء للتراث العربي النفسي على حد علم الباحثة. ه- مـن الاهميـة التطبيقيـة أنها تقدم بـرامج ارشـادية للوالدين للحد مـن ابتزازهم لأبنـائهم.

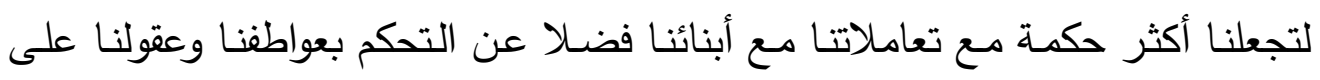
الوجه الامثل وتبنى معايير واقعية واهداف سلوكية للمسئولية الاجتماعية.

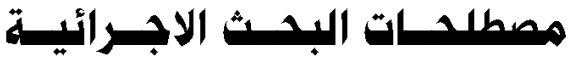

\section{Emotional Blackmail الابتزازالعاطفي}

\section{هناك تعريفات لغوية واصطلاحية واجرائية:}

من الناحية اللغوية مأخوذة من الفعل الثلاثي بزز يقال بزز الثيء بزا أى سلبه واغتصبه

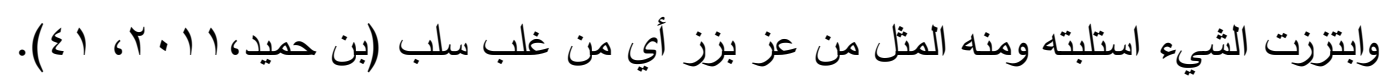


أما من الناحية الاصطلاحية فالابتزاز العاطفي هو نمط سلبى من التعامل يلجأ فيه أحد الطرفين الى استغلال الطرف الاخر وهو شكل من أشكال التلاعب الفعالة والذى يهددنا فيـه الاشخاص المقربون من سواء بطريقة مباشرة أو غير مباشرة ليعاقبونـا اذا لم نفعل ما يريدونـه

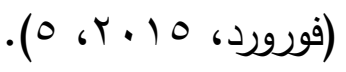

وتتبنى الباحثة هذا التعريف في اعدادها وتصميم المقياس الذى تطبقه على عينة البحث. أما عن التعريف الإجرائي هو الدرجة الكلية التي يحصل عليها المفحوص على فقرات مقياس الابتزاز العاطفي الذى يتكون من ثلاث أبعاد (الخوف - الالزام - الثعور بالذنب) الذى أعدته الباحثة.

\section{Emotional Attachment Patterns أنماط التعلق الوجلاني}

يمثل الرابطة العاطفيـة بين الابناء ووالديهم يشكلها الطفل مـع مقدم الرعايـة الاساسية وتصبح فيما بعد أساسا للعلاقات الحب المستقبلية تؤدى الى الثعور بالسعادة والفرح والامن عندما يكونـون بـالقرب مـن مقدم الرعايـة الأساسـي، والثـعور بعدم الارتيـاح والتوتر عندما ينفصلون منه مؤقتا (Lafroniere, P., 2000, 23). ويتبنى الباحثان هذا التعريف في اعداد مقياس أنماط التعلق للمراهقين.

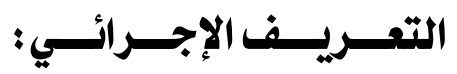
الدرجة الكلية التي يحصل عيها المستجيب على فقران مقياس انماط التعلق الوجدانى الذى أعده أبو غزال وجرادات (9 . . ( ).

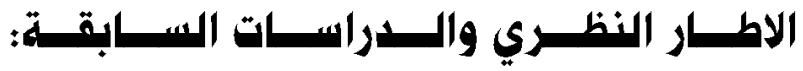

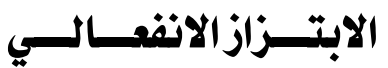

نتعلم من غير قصد أن نكون منبوذين ومعادين للناس بسبب بعض أشكال الاساءة العاطفية التي نتعرض لها في مراحل النمو المختلفة التي يمارسها الاباء علينا ومن أخطر اشكال التلاعب وألياتها هي الابتزاز والاكراه، وهما من المصطلحات الحديثة التي لم تتطرق إليها الدراسات النفسية على حد علم (fog) (fear, obligation, and guilt) الباحثة، فالابتزاز العاطفي يتمثل في ثلاث محاور اساسية وهى اختصار للخوف والتهديد والالزام والثعور بالذنب وتستعرض الباحثة هذه المصطلحات. 
1- الخوف: وهو يمثل أحد مكونات الابتزاز العاطفي حيث يبنى المبتز استراتيجيات واعية وغير واعية بناء على المعلومات التي يعطيها لله الطرف الاخر بشأن مـا يخاف منـه طول فترة العلاقـة العميقـة مـع الطرف الاخر ، كمـا يلاحظ الاشياء التي يهرب منها وتصيبه بالقلق وتمثل هذه المعلومات ذخيرة يمكن المبتز من خلالها التوصل الى اتفاق

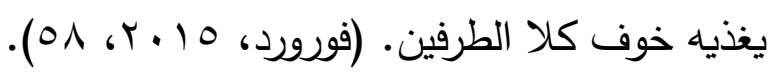

r- الالزام: فالمبتز لا يتردد أبدا في اخضاع احساس الطرف بالالتزام للاختبار، حيث يؤكد مقدار مـا تخلى عنه، ومقدار مـا فعله من أجله، ومقدار مـا يدين الطرف الاخر لـه، وربمـا يسـتخدم مـا يعزز موقفـه مـن التعـاليم الدينيـة والتقاليد الاجتماعيـة ليؤكد مـى

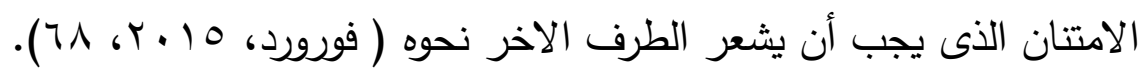
ب- الثعور بالذنب: يمثل الجزء الأساسي من كون الفرد عطوفا لديه حس المسئولية وتوبيخ

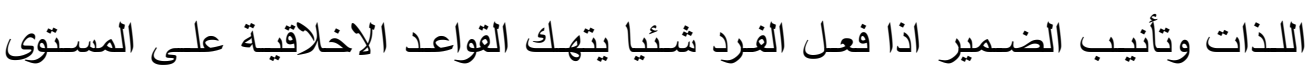
الشخصـي والاجتمـاعي ولكى يتجنـب الثـعور بالـذنب فيحـاول تجنـب الحساق الاذى والضـرر بـالأخرين، والثـور بالذنب الذى يثيره المبتز يهاجم احسـاس من يبتزه بانسه شخص محبوب ذو قيمة الامر الذى يشعره بانه مسئول عن ألم المبتز ويصدقه عندما يخبره بانه يضاعف بؤس المبتز من خلال عدم تلبية رغباته (محمد، 7 ( ـ 1، I ). يتضـح مما سبق أن عملية الابتزاز تتطلب طرفين فهي عملية ثائية وليست فردية فهناك المبتز وهو القائم بعملية التهديد والمساومة وهناك الطرف الأخر الضحية الثخص الواقع عليه التهديد

والمساومة وكلا منهما له سيكولوجيته وسماته الثخصية الخاصة والتي تعد جزءا من شخصيتهما. نلجأ غالبًا إلى الابتزاز لأنـه قد يعطينا السيطرة على الابنـاء عندما لا نعرف كيفيـة الحصول عليها بطريقة أخرى، فالسيطرة ليست مرادفا للتعليم. إن إخبار أطفالنا بما يجب عليهم فعله، وكيفية القيام بـه، وتهديدهم إذا لم يفعلوا ذلك على الفور ، يقلل من قدراتهم على اتخـاذ القرارات إلى الحد الأدنى. هذا يخلق أرضـا خصبة لهم ليكونوا إمـا مفرط الاعتمـاد أو متمرد

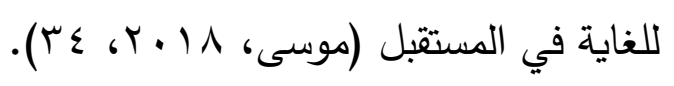
وأوضح بيتربلاو (1964)Peter Blaw في نظريته الخاصة بالتبادل الاجتماعى لتفسير العلاقات الاجتماعيـة بين الافراد القرببين مثل الاصـدقاء أو الازواج أو الابـاء والابنـاء وهذه 
النظريـة تفسر الابتزاز العاطفي من الوجهة الاجتماعية ،وتوضح أن مفهوم القوة التي يمارسها

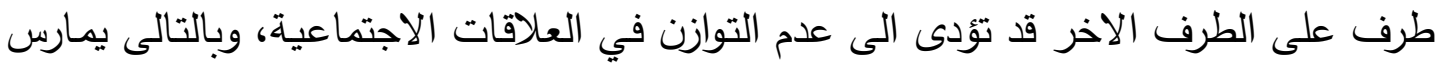
الطرف الاقوى فرض الاذعان والخضوع عن طريق الاجراءات السلبية في حال عدم امتثال

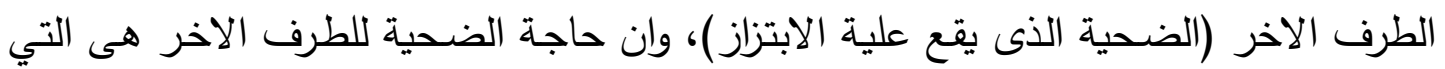

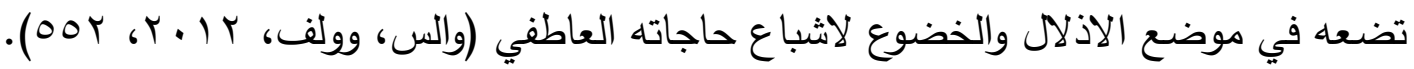

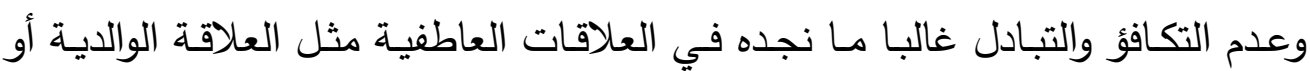
علاقة الزوج بالزوجة فعندما نجد أن الاب أو الابن يحب احدهما اكثر فنجده يقدم كل التتازلات والمكأفات من أجل أن يحظى بحبه لغرض استمرار العلاقة ويرى أن القوة هى أساس التبادل

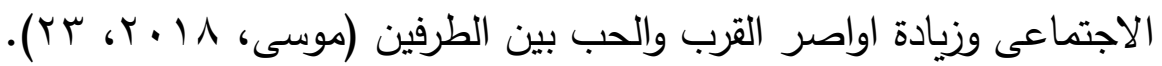
وهناك تفسير اخر للابتزاز العاطفي من قبل المعالجة النفسية سوزان فوروورد (99v) أوضحت فيه أن هنالك كم كبير من الاذكياء الماهين الذين يجدون انفسهم يبحثون عن طرائق لفهم

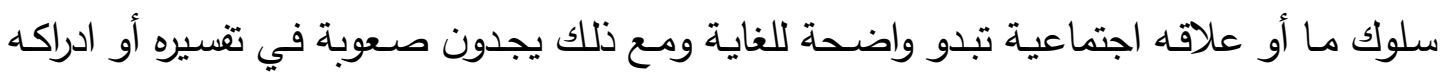

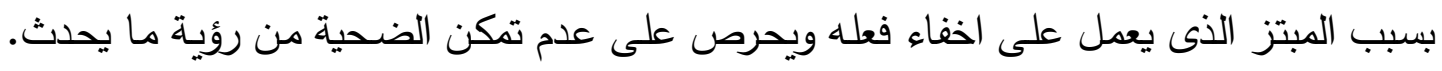

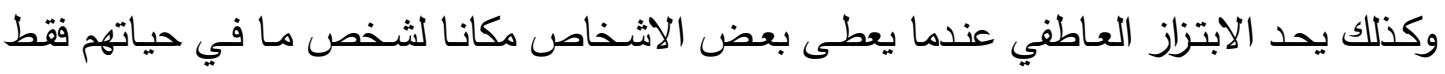
ليكتسبوا منه الجب والاحترام اذ ليس لايهم القدرة على أن يؤمنوها لذواتهم (فوروورد، 10 ـ بـ، 9 (1). وهناك خطوات يتبعها المبتز لكى يسيطر على الضحية منها: 1- الطلب عندما يطلب المبتز من الضحية (بنحو مباشر أو غير مباشر) القيام بفعل شئئا

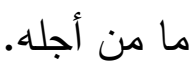
r- المقاومة: عندما يظهر الضحية رفضه وقلقه من هذا الطلب. r- الضغط: عندما يضيق على الضحية الخناق ويجعله في زواية ضيقة.

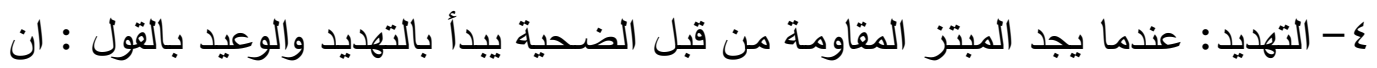
عدم قيام بما يريده سيكون له عواقب وخيمة.

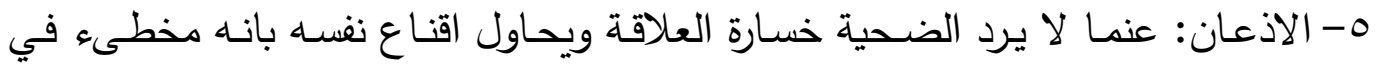
الاعتراض هنا يبدأ للاستسلام والقيام بما يريده المبتز .

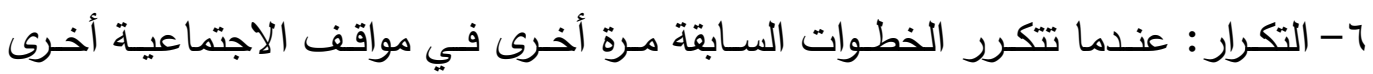

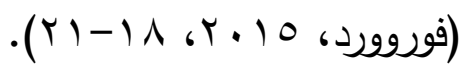




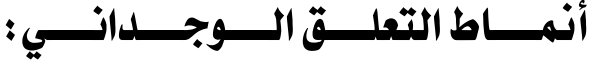

يعد التعلق الوجداني أحد اشكال العلاقات الحميمـة التي أولاهـا علمـاء النفس قديما وحديثا الاهتمام المكثف محاولين الكثف عن طبيعة هذه العلاقة ومدى استمراريتها في المراحل النمائية الناحقة واثرها في كافة الجوانب التطور الانفعالى والاجتماعى والمعرفى وفى علاقاته

المستقبلية وتفاعلاته اليومية في مواجهة مشكلاته الاجتماعية وتوافقه الاجتماعى بثكل عام.

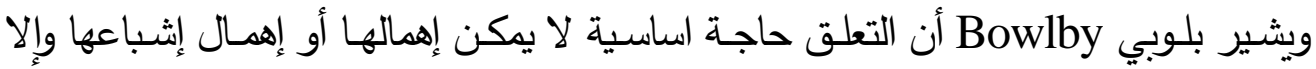
إضيرت الثخصية وأعيق نموها فالاطفال يولدون ولديهم حاجة للحب والامن وإقامة العلاقات علاقات حميمة وامنه مع اشخاص معينين بهم يمدونهم بمزيد من الدساندة والتثبل (كرم الدين، ( ...r، 1 (1). ورابطة التعلق بالوالدين تستمر حتى طوال مرحلة الرشد وتظل تؤثر في السلوك بأشكال لا يمكن حصرها، وبذلك يشكل التعلق رابطة وجدانية قوية ثابتة لفترة طويلة نسبيا فيها الاخر كفرد

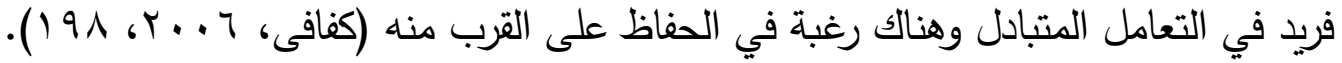
فالتعلق الوجدانى لـه أساس بيولوجى للارتباط يبنى على أساس على التركيب الجيني، فالدافع إلى البقاء على قيد الحياه دافعا أساسيا لدى كل الكائنات الحية ويولد الطفل وهو عاجز تماما وبالتالى يتوقف وجوده على قيد الحياه على وجود الاخرين الذين يقدمون له الرعاية، فاللأم السوية بدنيا وانفعاليا ترتبط بطفلها وتشعر بكل ما ينتابه من تقلبات من خلال اقترابه البدني منها ولمسه ومداعبته واحتضانه ويستجيب الطفل بالتبعية لهذه السلوكيات من خلال الاقتراب والمناغاة

والابتسام والرضاعة والتثبث بالام (Benjamin, J \& Virginia, k, 2004, 141). وعليه بالرغم من الاساس البيولوجي، فان جودة خبرات الحياة المبكرة التي تعبر عن هذا الاساس البيولوجى هى التي تحدد شكل التعلق والارتباط، وبدون نعرض الطفل لرعاية وأساليب معاملة

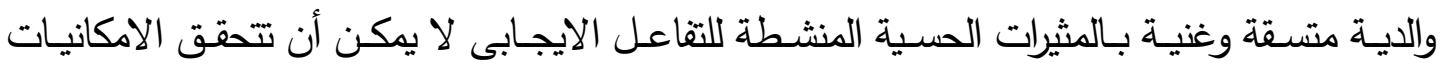
النمائية الفطرية للتعلق والارتباط السوى التي يولد كل الاطفال مزودين به (Bruce, p , 2006, 12).

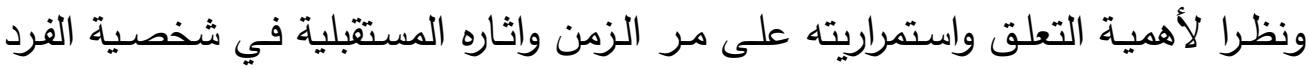
وتوافقه النفسي والاجتماعى فقد طور (Bartholomew, \& Horowitz, 1991) أربعة أنماط من التعلق الوجدانى وهى التعلق الامن ويتميز أفراد هذا النمط بنظرة ايجابية للذات والاخرين،

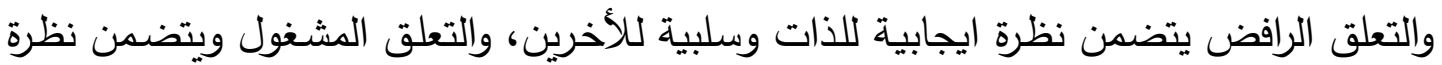


سـلبية للذات ونظـرة ايجابيـة للأخرين، والاخيـرة التعلق المرتعب ويتميز بنظـة سلبية للذات

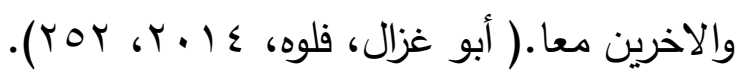

كما أن هناك عدة عوامل يمكن أن تؤثر تأثيرا واضحا على نشأة وتطور قدرات التعلق فعندما تختل علاقات التفاعل أو التناغم بين الطفل والقائمين على شئون تتشئته ورعايته وتعليمه يتعـذر بنـاء خبـرات التعلق السوية ومـن هذه العوامـل الطفل والبيئة والقـائمين على الرعايـة. .(Jennifer, N, \& Donna, F, and Horbury, A, 2001, 127)

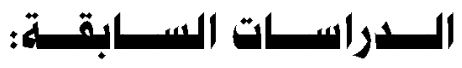

الدراسات السابقة التي تناولت الابتزاز العاطفي وعلاقته ببعض المتغيرات النفسية. • دراسـة ليـونج (Laung, A. 2005 ) التي تناولت علاقة الابتزاز والتلاعب العـاطفي وعلاقته بالثراء لدى المستهلكين، واوضحت نتائج الدراسة الى أن هناك من الموظفين في مجالات التسويق يستغلون ويبتزون العملاء أثناء الشراء. • دراسة شين (Shen, S. 2009 ) التي تتاولت تحديد أنواع العملاء في مجالات الخدمات الماليـة الذين يتبنـون أنماطسا مختلفـة مـن الابتزاز الانفعـالى نحو مـوظفي خدمـة العمـلاء، وتكونت العينـة مـن (TM) مـن مـوظفي خدمـة العمـلاء طبق عليهم المقـابلات الثخصـية والاستبانات، وأثـارت نتائج الدراسـة ان هنالك خمسـة أنماط من العمـلاء الذين يستخدمون الابتزاز العاطفي للحصول على حاجتهم ورغباتهم.

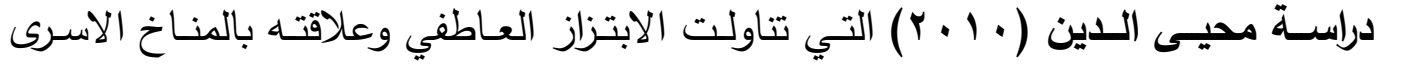
وبعض المتغيرات الشخصية لدى طالبات المدارس الثانويـة (دراسـة سيكو متريـة إكلينيكية)، وكانت عينة البحث مكونـة من . طالبة في المرحلة الثانويـة، وأوضحت نتائج الدراسـة الى وجود علاقة دالـة احصـائيا بين الابتزاز الانفعالى الوالدي والمنـاخ الاسرى والعمليات الاسرية السلبية، كذلك وجود علاقة دالة احصائيا بين الابتزاز العاطفي الوالدي ومتغيرات الشخصية الايجابيـة وكذلك اختلاف البنـاء النفسي للمنخفضـات الابتزاز العـاطفي وبين المرتفعات في الابتزاز العاطفي من خلال الدراسة الإكلينيكية. ه دراسـة شيوليو (Shu, liu, 2010) التي تناولت العلاقة بين ادراك الموظفين للابتزاز العاطفى ورفاهتهم الذاتية لدى عينـة من الموظفين العاملين بشركة في مدينة تايوان وكان 
عددهم (r99) من الذكور والانـاث وأشـارت نتائج الدراسـة الى وجود ارتباط سـالب دال احصائيا بين التهديد واللوم كأحد مكونات الابتزاز العاطفى ورفاهيتهم الذاتية :كما لا يوجد

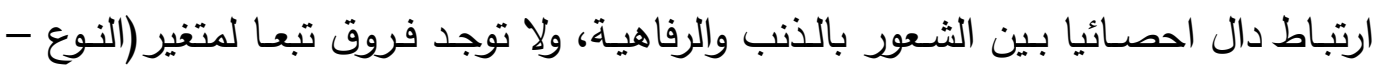
المستوى التعليمي - الحالة الاجتماعية). دراسة شين (Shen, S, 2010) التي تتاولت دراسة الميكا فيلية كسمة من سمات المبتز

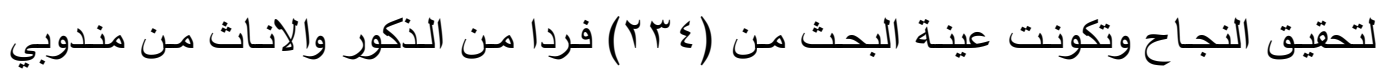
المبيعات، وقد أوضـت نتائج الاراسة إلى وجود علاقة دالة احصـائيا بين الميكا فيلية

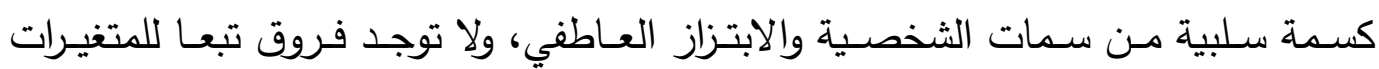
الديموغرافية (النوع - السن - المستوى الاجتماعى - الدكانة الاجتماعية).

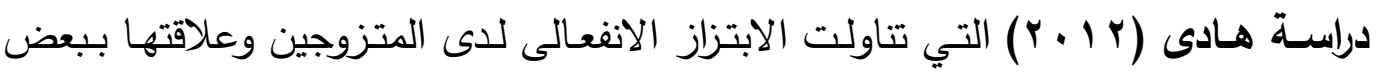

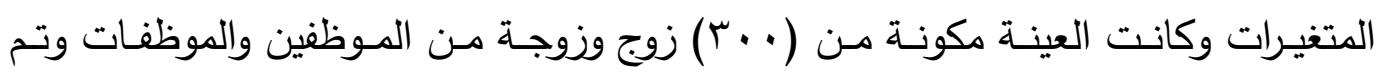
التوصل الى وجود فروق دالة احصائيا ين المتزوجين في الابتزاز العاطفى وفقا لمتغير مدة الزواج، أى كلما قلت مدة الزواج زاد الابتزاز العاطفي والعكس صحيح.

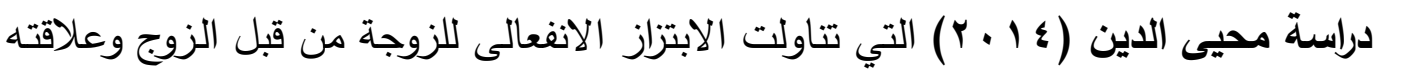

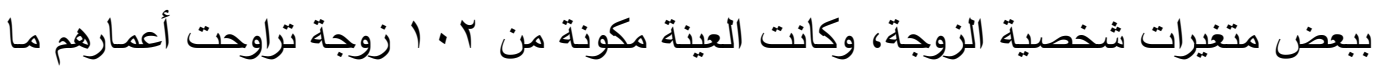

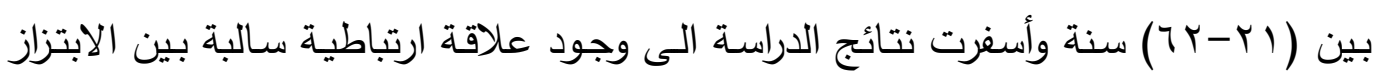
الانفعالى للزوجة من قبل الزوج ومتغيرات الثخصية الايجابية (تقدير الذات- السعادة الاستقلالية) بينمـا توجد فروق دالـة احصـائيا بـين متوسط درجـات منخفضـات الابتزاز الانفعالى من الزوجات ومرتفعات الابتزاز الانفعالى من الزوجات في متغيرات الثخصية السلبية (القلق - الوسواس القهرى - توهم المرض - الثعور بالذنب).

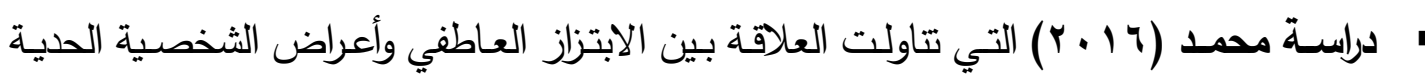

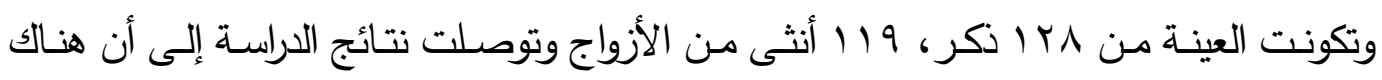

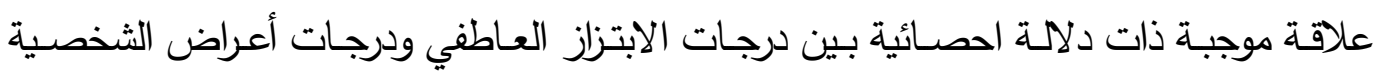
الحدية وكذلك عدم وجود فروق ذات دلالة احصائية بين الأزواج والزوجات في متغيرات الدراسة. 


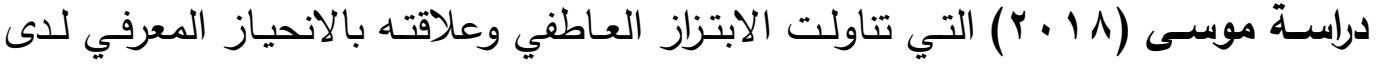
المعلمين بالمدارس ـ تكونت العينـة مس V IV معلم ومعلمـة طبق عليهم مجموعـة مـن المقـاييس (مقيـاس الابتزاز العـاطفي - مقيـاس الانحيـاز المعرفي - مقيـاس المسئولية

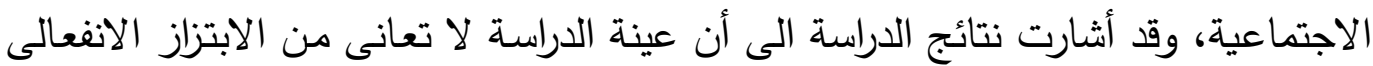
وانهم يتمتعون بالمسئولية الاجتماعية وأن هناك علاقة دالة احصائية سلبية بين الابتزاز العاطفي والمسئولية الاجتماعية والانحياز المعرفي.

الدراسات التي تناولت أنماط التعلق الوجدانى وعلاقته ببعض المتغيرات النفسية:

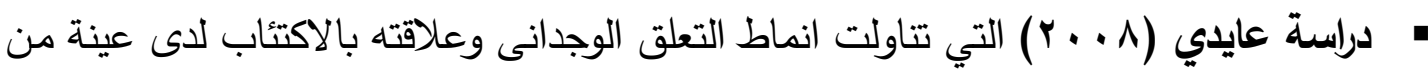

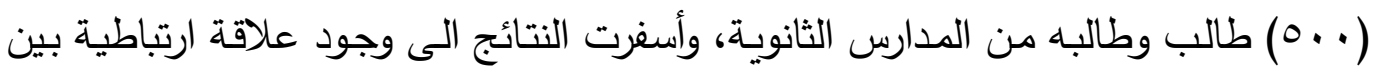
درجات كلا من أنماط التعلق الوجدانى ودرجات الاكتئاب لاى عينة الدراسة كما يختلف البناء النفسي وديناميتا الثخصية حسب انماط الثخصية وذلك من خلال الدراسة الإكلينيكية.

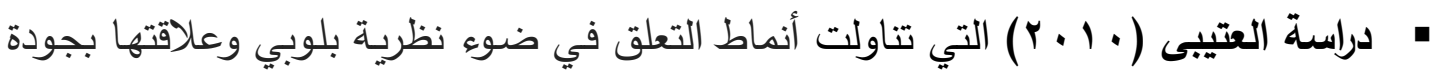
الحيـاة لـدى طالبـات المرحلـة الثانويـة بمدينـة الريـاض والعلاقـة بين أنمـاط التعلق بـالأم

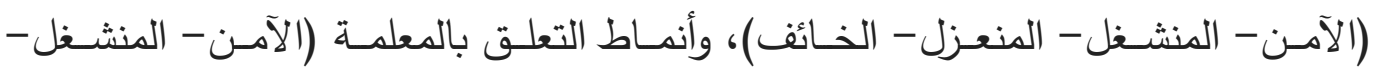

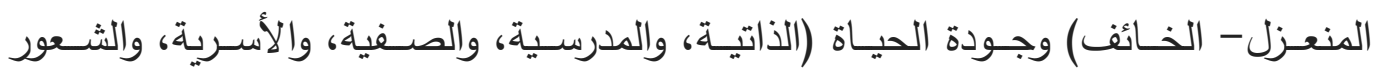

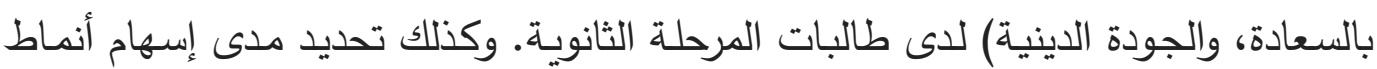
التعلق في التتبؤ بجودة الحياة، واستخدمت الدراسة المنهج الوصفي (الارتباطي- السببي

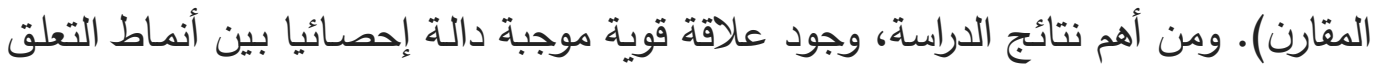

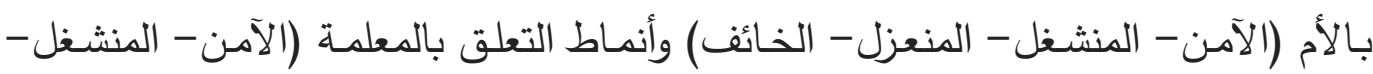

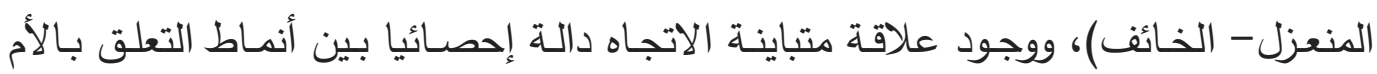
وجودة الحيـاة للدى طالبات المرحلـة الثانويـة، حيث كانت العلاقـة متوسطة القوة موجبـة الاتجاه بين نمط التعلق الآمن وجودة حياة الطالبة، ومتوسطة القوة سالبة الاتجاه بين أنماط

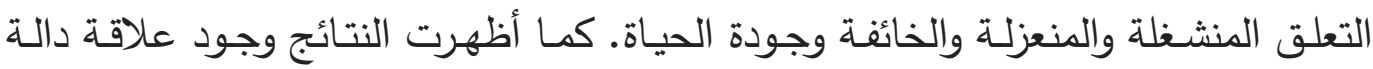
إحصائيا بين أنماط التعلق بالأم وبعض أبعاد جودة الحياة. 
د/ نعمات قاسم الابتزاز العاطفي لدى الابناء من قبل الوالدين وعلاقته بأنماط التعلقع الوجداني لدى عينة من الطلاب الهدراس الثانوية

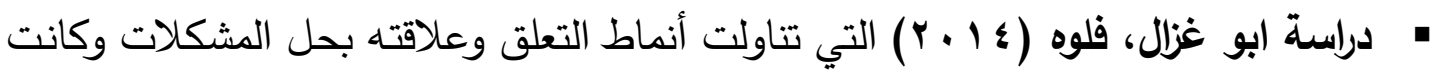

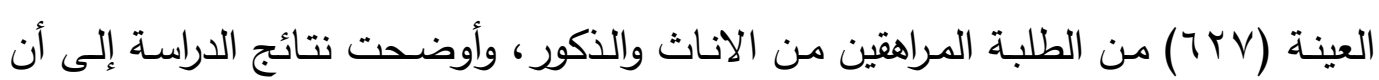

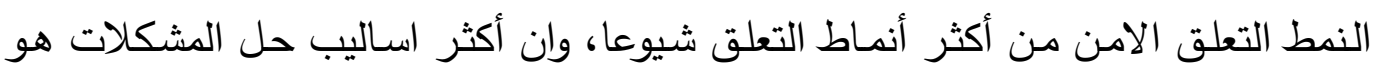
أسلوب حل المشكلات العقلاني.

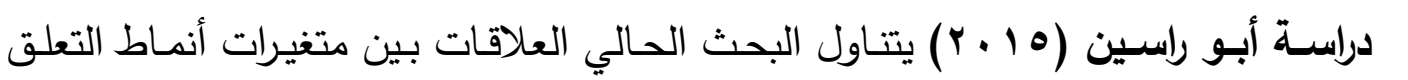

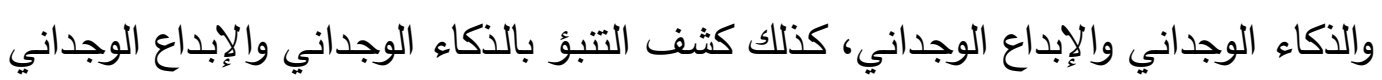

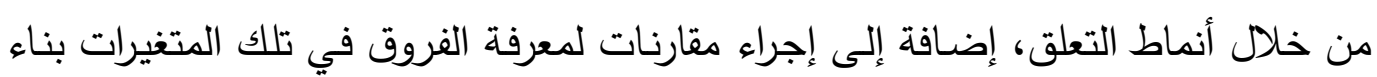

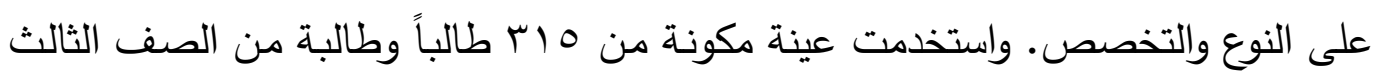
الثانوي (109 طالباً، و 107 طالبة)، طبق عليهم ثلاثة مقاييس من إعداد الباحث: أنماط

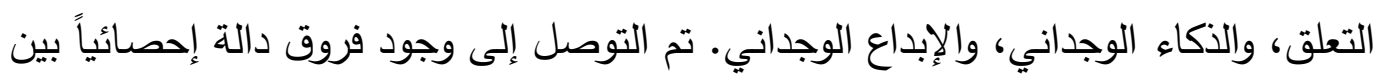

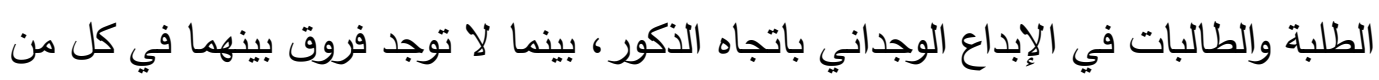

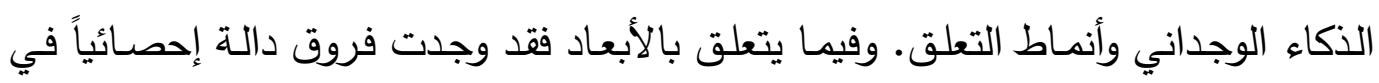

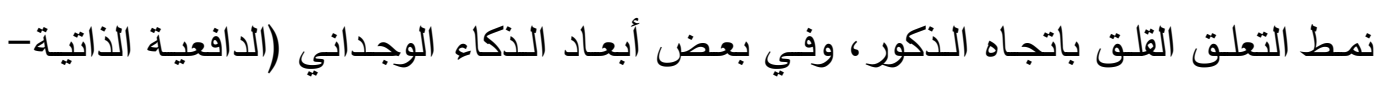

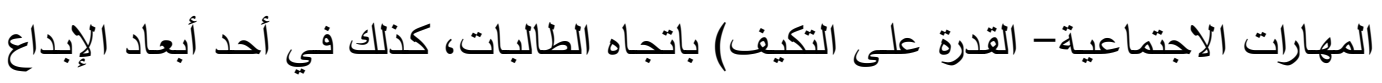

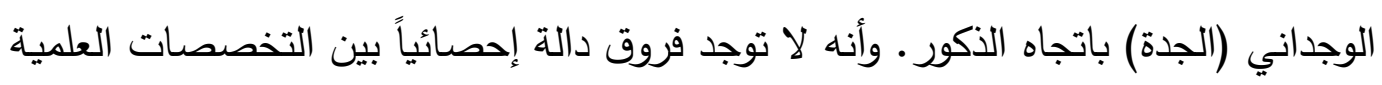

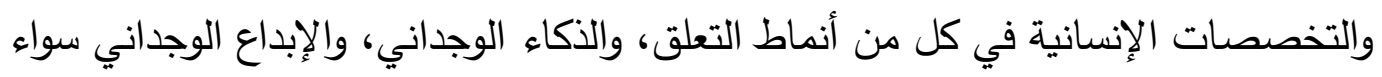

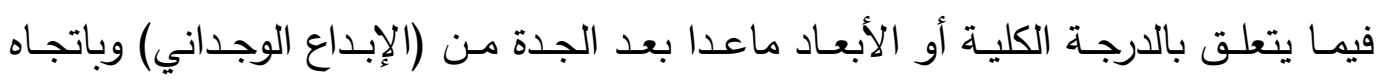

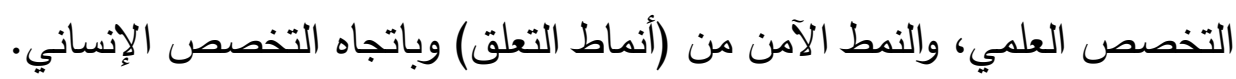
دراسة سيرين (2017, Şirin, H,) التي تتاولت أنماط التعلق وعلاقتها بالتشوهات المعرفية الإنية.

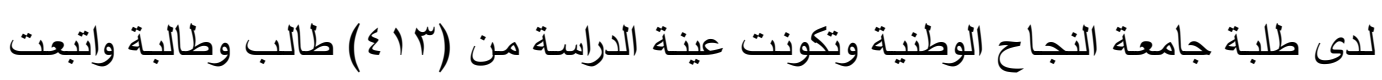

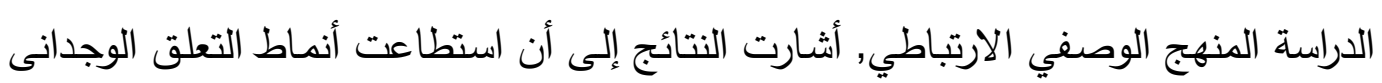

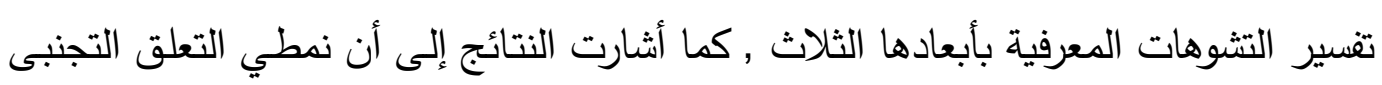
والقلق استطاعا التتبؤ بتشوه معرفي غير واقعي في العلاقة وتشوه سوء الفهم بين الأفراد.

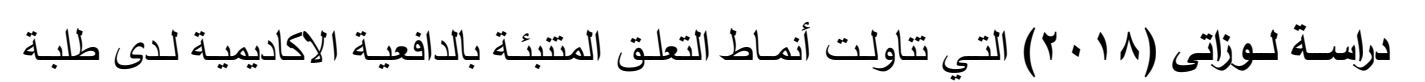

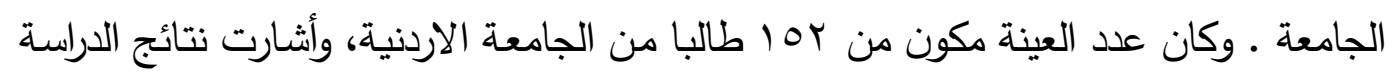


إلى ان النمط التعلق الامن والتجنبى يرتبطان بالتتبؤ بالدافعية الاكاديمية بشكل إيجابي، وأن النمط المشغول البال والقلق لا يرتبطان بالتتبؤ بالدافعية الاكاديمية لدى طلبة الجامعة.

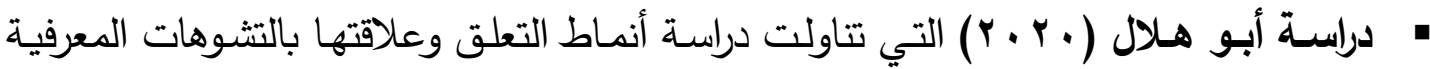
لدى طلبة جامعـة النجاح الوطنية، كما هدف إلى الكثف عن الفروق في أنماط التعلق والتشـوهات المعرفيـة تعزى متغيرات: الجنس والترتيب الوالدي، استخدمت الباحثة المنهج الوصفي ابل رباطي في إجراء الدراسة، واستخدمت مقياس أنماط التعلق، ومقياس التشوهات

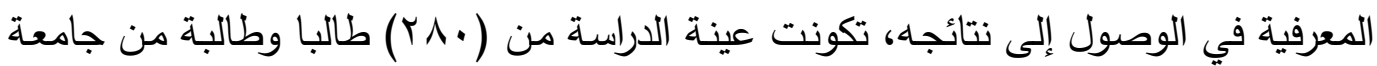

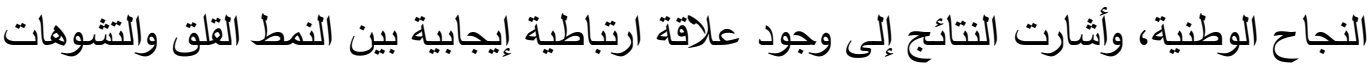

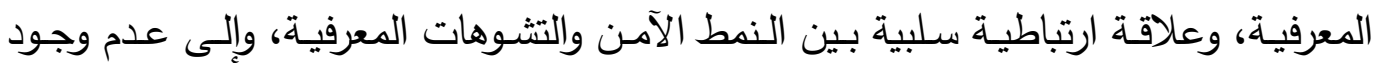

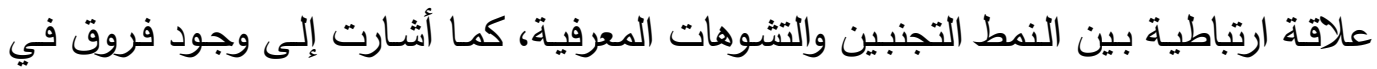
النمط القلق تعزى إلى الجنس لصـالح الذكور ، وعدم وجود فروق في النمط الآمن والنمط التجنبين تعزى إلى الجنس، وعدم وجود فروق في أنماط التعلق تعزى إلى الترتيب الوالدي،

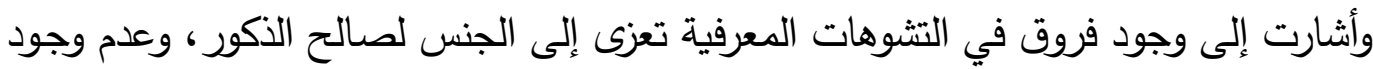
فروق في التشوهات المعرفية تعزى إلى الترتيب الوالدي لدى طلبة جامعة النجاح الوطنية.

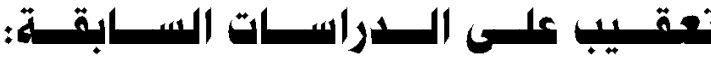

من سرد الدراسات السابقة وجدت الباحثة ندرة الدراسات والبحوث التي تتناول الابتزاز

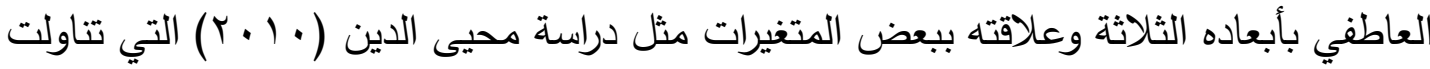

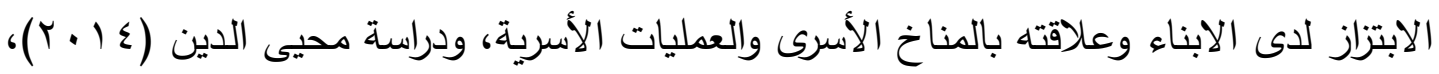

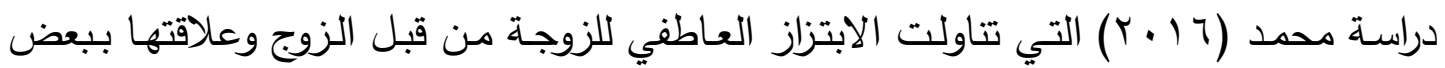
اضطرابات الثخصية، ودراسة موسى (1) • (1) التي تتاولت الابتزاز الانفعالى للى المعلمين

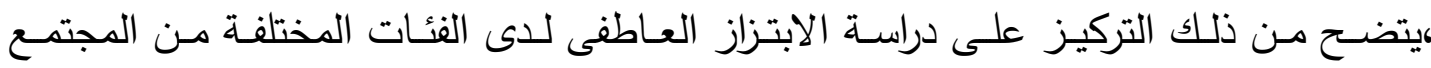

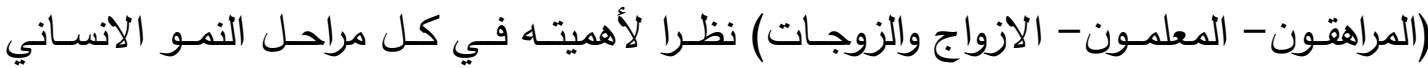

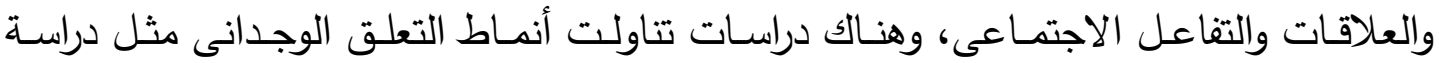

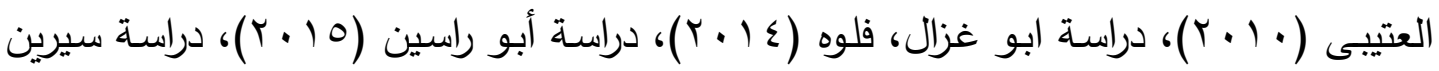
(Y.ririn, H, 2017) 
يتضح دن الدراسـات السابقة عدم وجود دراسـة واحدة تناولت هذين المتغيرين (الابتزاز

العاطفى، أنماط التعلق الوجدانى) على حد علم الباحثة فلذلك اختارت الباحثة طلاب المرحلة الثانويـة لدراسـة العلاقة بين الابتزاز العاطفى وأنماط التعلق الوجدانى وتأثير بعض المتغيرات الديموجرافية (الجنس، المستوى التعليمي للوالدين) على كل من المتغيرين.

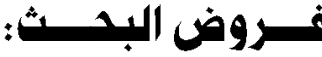

1- يوجد علاقـة ذات دلالمة احصـائية بين الابتزاز العاطفي وأنماط التعلق الوجداني لدى

عينة البحث.

r- ما مستوى الابتزاز العاطفي لدى عينة البحث؟

r- ما أكثر أنماط التعلق الوجدانى شيوعا لدى عينة البحث؟

ع- توجد فروق ذات دلالة احصائية بين متوسطات درجات الطالبات ومتوسطات درجات

الطلبة في مستوى الابتزاز العاطفي.

0- توجد فروق ذات دلالة احصائية بين متوسطات درجات الطالبات ومتوسطات درجات

$$
\text { الطلبة في مقياس أنماط التعلق الوجداني. }
$$

צ- يوجد فروق ذات دلالة احصائية بين متوسطات درجات أفراد العينة في مستوى الابتزاز

العاطفي وفقا لمتغير المستوى التعليمي للوالدين (الجامعي - الغير الجامعي).

V يوجـد فـروق ذات دلالــة احصـائية بـين متوسـطات درجـات أفـراد العينـة في أنمـاط

التعلـق الوجــدانى وفقــا لمتغيـر المســتوى التعليمــي للوالــدين(الجامعي - الغيـر

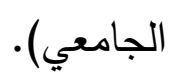

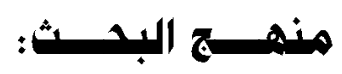

تختلف المناهج البحثية باختلاف مواضيع البحث من حيث تتوع المتغيرات المدروسـة

ولما كان موضوع الدراسة يتمثل في دراسة العلاقة بين الابتزاز العاطفي وأنماط التعلق الوجداني فإن المنهج الذى يناسب هذا البحث هو المنهج الوصـفي الذى يقوم على تحليل المتغيرات المنوط به البحث وعلاقته بالمتغيرات المؤثرة فيها. 


\section{هــدةت البدـثـ:}

تتحدد حدود البحث بالعينة التي يطبق عليها أدوات البحث وهم طلاب المرحلة الثانويـة

من الجنسين الذكور والاناث وعددهم • اب من طلاب الصف الأول الثانوي أعمارهم ما بين

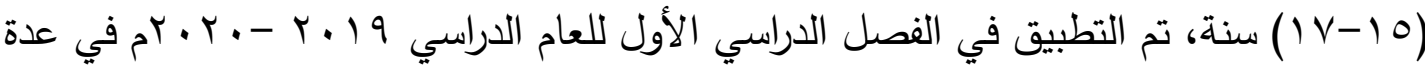
مدارس بالمملكة العربية السعودية في محافظة المجمعة تكونت عينة البحث من · اب طالب وطالبة موزعة على النحو التالي.

جلدول (1) توضح التوزيع النسبي لأعداد الذكوروالاناث في عينة البحث

\begin{tabular}{|c|c|c|}
\hline الـــــــــــــور & الانـــــــــــاث & اســــــم المـــــــرســـــة \\
\hline- & rr & الثانوية الاولى للبنات بالمجمعة \\
\hline- & $\xi r$ & الثانوية الثانية للبنات بالمجمعة \\
\hline- & $\Sigma 7$ & الثانوية السادسة للبنات بالمجمعة \\
\hline$\$ 9$ & - & الملك عبد الله الثانوية بنين بالمجمعة \\
\hline$\$ 1$ & - & الملك فهد الثانوية بنين بالمجمعة \\
\hline
\end{tabular}

يتضح من الجدول(1) أن عدد الاناث · r 1، وعدد الذكور · . 9.

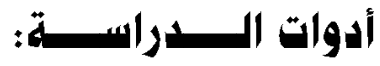

\section{ا- مقياس الابتزاز العاطفي : من إعداد الباحثة}

أ) مــبررات اعسـاد المقيــاسر:

بالاطلاع على التراث النظري والدراسات السابقة والمقاييس الخاصـة بالابتزاز الانفعالى

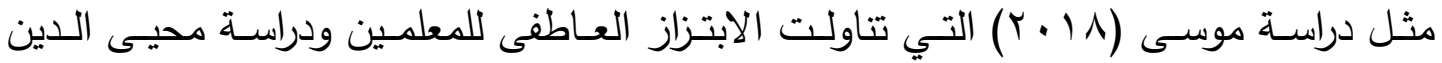

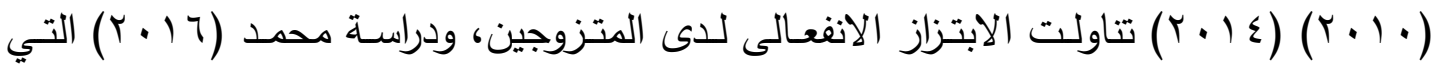
تتاولت الابتزاز الانفعالى لدى الزوجة، ودراسة محيى الدين التي تتاولت الابتزاز العاطفى لدى طالبات المرحلة الثانويـة، وجدت الباحثة أن هناك اختلاف فى تصميم أبعاد المقياس وكذلك العبارات المكونة لكل بعد وذلك لأسباب تتعلق بالعينة وخصائصها فلذلك اجتهدت الباحثة في 
د/ نعمات قاسم الابتزاز العاطفي لدى الابناء من قبل الوالدين وعلاقته بأنماط التعلةع الوجداني لدى عينة من الطلابا الهدراس الثانوية

وضـع أبعاد مشتركة تتاسب عينـة البحث مـع الأبعاد الخاصـة للمقاييس سـابقة الذكر، وكذلك لتتاسـب المجتمع السـودي الذى يتسـم بـالتحفظ والالتزام الديني، وقد تمـت صـياغة عبـارات المقياس على أسـاس ثـلاث أبعاد وهم (الخوف والالزام والثـعور بالذنب) التي تحدثت عنهم فوروود (99V ( ) ) في كتابها سابق الذكر •

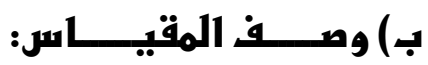

يتكـون المقيـاس مـن ثـلاث أبعـاد كمـا ذكـر ، كـل بعـد يثـمل على عشـرة عبـارات،

فيكـون مجمـوع عبـارات المقيـاس • ب عبـارة، تصـحح كـل عبـارة بأربعــة اختيـارات (ينطبـق على تمامًَا، ينطبـق على غالبَّا، ينطبـق على أحيانًا، ينطبـق على نـادرًا) تتـراوح الـدرجات لكل بعد من ( (1-، ع).

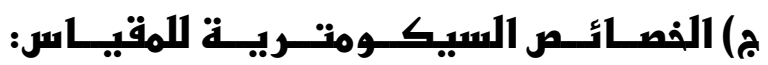

تـم التحقـق مـن صـدق وثبـات المقيـاس مـن خــلال تطبيـق المقيـاس علـى العينــة الاستطلاعية مكونة من (Y乏) طالب وطالبه بالطرق التالية.

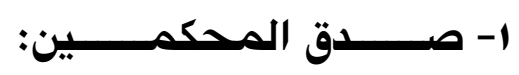

قامت الباحثة بعرض المقياس في صـوته الأولية على مجموعـة من المحكمين فى مجال التربية وعلم النفس (خمسة من أعضاء هيئة تدري)، للحكم على مدى صـلاحية الفقرات من حيث مدى انتماء كل فقرة إلى البعد الذي أدرج تحته، وإمكانية إضـافة أو حذف أو تعديل بعض الفقرات، إضـافة أي ملاحظـات أو توجيهات يرونها ضـرورية لصدق الاستبانة. وجـاء نتيجة ذلك أن تم تعديل الصياغة اللغوية لبعض الفقرات. r- الاتســاق الــداخلــــي: قامت الباحثة بالتحقق من صدق المقياس وذلك من خلال حساب العلاقة الارتباطية بين درجات أفراد العينة على كل فقرة من الفقرات والبعد الذي يقيسها من خلال معامل ارتباط بيرسون، وقد جاءت جميع معاملات الارتباط المحسوبة دالـة إحصـائياً عند مستويات دلالـة مقبولة، مما يثير ذلك إلى صدق المقياس كما موضح بالجدول التالي 
جلول (r) معاملات الارتباط درجات أفراد العينة على كل ققرة

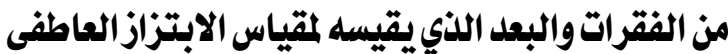

\begin{tabular}{|c|c|c|c|}
\hline مستوى اللالة & معامل ارتباط الفقرة بالبعد الذي يقيسها & البعد الذي يقيسها & رقمر الفقرة \\
\hline$\cdot, \cdot 1$ & **•, Yar & \multirow{10}{*}{ الخــــــــوف } & 1 \\
\hline$\cdot,+1$ & $* * \bullet, V \leqslant r$ & & $r$ \\
\hline$\cdot,+1$ & $* * \bullet, \wedge \xi \bullet$ & & $r$ \\
\hline$\cdot,+1$ & $* * \bullet, Y Y \wedge$ & & $\xi$ \\
\hline$\cdot, \cdot 1$ & $* * \bullet, V \vee \bullet$ & & 0 \\
\hline$\cdot,+1$ & $* * \bullet, Y r V$ & & 7 \\
\hline$\cdot,+1$ & $* * \bullet, r \cdot r$ & & $v$ \\
\hline$\cdot,+1$ & **•, YT\& & & $\wedge$ \\
\hline$\cdot,+1$ & $* * \bullet, \wedge 11$ & & 9 \\
\hline$\cdot, \cdot 1$ & $* * \bullet, V \leqslant 7$ & & 1. \\
\hline$\cdot,+1$ & $* * \bullet, \vee \neg ฯ$ & \multirow{10}{*}{ الالــــــزاهـ } & 11 \\
\hline$\cdot, \cdot 1$ & $* * \bullet, \Lambda \cdot \xi$ & & ir \\
\hline$\cdot, \cdot 1$ & $* * *, \wedge \|$ & & ir \\
\hline$\cdot,+1$ & $* * \bullet, \vee \vee \varepsilon$ & & $1 \varepsilon$ \\
\hline$\cdot,+1$ & $* * \bullet, \vee \wedge \neg$ & & 10 \\
\hline$\cdot,+1$ & $* * \bullet, \wedge \leq V$ & & 17 \\
\hline$\cdot,+1$ & $* * \bullet, Y \wedge \vee$ & & iv \\
\hline$\cdot,+1$ & $* * \bullet, \Lambda \cdot V$ & & 11 \\
\hline$\cdot,+1$ & $* * \bullet, \wedge \mid \Lambda$ & & 19 \\
\hline$\bullet,+1$ & $* * \bullet, \wedge Y \wedge$ & & $r_{0}$ \\
\hline$\cdot, \cdot 1$ & $* * \bullet, 77 \Lambda$ & \multirow{10}{*}{ الشعـــورباللنب } & MI \\
\hline$\cdot,+1$ & $* * \bullet, \wedge 71$ & & $r r$ \\
\hline$\cdot, \cdot 1$ & **๑, $\vee$ Y & & rr \\
\hline$\cdot, \cdot 1$ & ***, VqY & & r乏 \\
\hline$\cdot,+1$ & $* * \bullet, \wedge 70$ & & ro \\
\hline$\cdot,+1$ & **॰, $\wedge \ 1$ & & YY \\
\hline$\cdot,+1$ & $* * \bullet, \vee \wedge \neg$ & & rV \\
\hline$\cdot,+1$ & $* * \bullet, \wedge \leqslant 1$ & & MA \\
\hline$\cdot,+1$ & 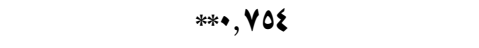 & & $r q$ \\
\hline$\cdot,+1$ & **•, Vor & & $r$. \\
\hline
\end{tabular}

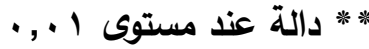

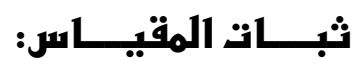
قامـت الباحث بـالتحقق مـن ثبات المقيـاس والابعـاد المكونـة لـه ككل وذلك باستخدام معامل ألفا لكرو نباخ، وذلك على النحو التالي: 
د/ نعمات قاسم الابتزاز العاطفي لدى الابناء من قبل الوالدين وعلاقته بأنماط التعلقع الوجداني لدى عينة من الطلاب الهدراس الثانوية

جدول (r) معامل ألفا لكرونباخ لحساب ثبات مقياس الابتزاز العاطفى

\begin{tabular}{|c|c|}
\hline 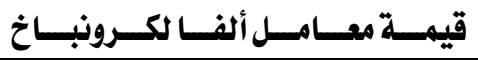 & الأبعــاد الخـــاصــة بـالمقيــاس \\
\hline •, ar & 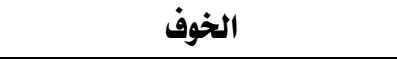 \\
\hline •,9r & 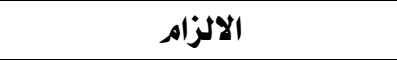 \\
\hline •,9r & الشعور بالذنب \\
\hline$\cdot, 97$ & المقياس ككل \\
\hline
\end{tabular}

يتضـح من جدول (r) أن قيمـة معامل ألفا لكرو نباخ لأبعاده والمقياس ككل مقبولة، مما يدل ذلك على ثبات المقياس.

ץ- مقياس أنماط التعلق الوجداثى للمراهقيز : إعداد أبو غزال وجردات (qه+r) يتكون المقياس من · r عبارة موزعة إلى ثلاثة أنماط من أنماط التعلق الوجدانى تتم الاجابة عنها من خلال أسلوب ليكرت ذي التدرج الخماسي، العامل الاول النمط التعلق الامن ويتكون من 7 فقرات تتراوح الدرجات ما بين 7 الى • ז، النمط الثاني النمط القلق ويتكون من V عبارات تتراوح الدرجات مـا بين V الى هب، والنمط الثالث النمط التجنبى ويتكون من 7

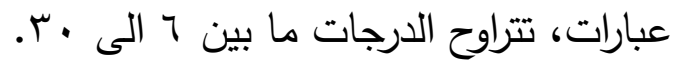
وقد تم التحقق من صدق المقياس وثبات المقياس بالطرق التالية:

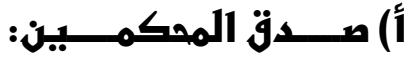
عرضت الباحثة المقياس فى صورته المعدة للتطبيق على مجموعة من الأسـاتذة فى مجال التربية وعلم النفس (خمسة من أعضاء هيئة تدري) للحكم على مدى صـلاحية العبارات الخاصة بالمقياس للمجتمع السعودي، وكانت نسبة الاتفاق أكثر من ه^\%؛ وهذا يعنى مناسبة مقياس أنماط التعلق الوجدانى للتطبيق على عينة الدراسة. ب) الاتنســاقو الــــافلـــي:

قامت الباحثة بالتحقق من صدق المقياس وذلك من خلال حساب العلاقة الارتباطية بين درجات أفراد العينة على كل فقرة من الفقرات والبعد الذي يقيسها من خلال معامل ارتباط بيرسون، وقد جاءت جميع معاملات الارتباط المحسوبة دالة إحصـائياً عند مستويات دلالـة مقبولة، مما يشير ذلك إلى صدق المقياس كما موضتح بالجدول التالي. 
جدول (§) معاملات الارتباط درجات أفراد العينة على كل فقرة من الفقرات والبعد الذي يقيسها

\begin{tabular}{|c|c|c|c|}
\hline مستوى الللالة & معامل ارتباط الفقرة بالبعد الذي يقيسها & البعد الذي يقيسها & رقم الفقرة \\
\hline$\bullet,+1$ & $* \bullet, 7 \vee q$ & \multirow{7}{*}{ القلـــــق } & 1 \\
\hline$\cdot, \cdot 1$ & $* * \bullet, 0 \leqslant Y$ & & $r$ \\
\hline$\bullet,+1$ & $* * \bullet, r 79$ & & $\Lambda$ \\
\hline$\bullet,+1$ & $* * \bullet, 7 r \wedge$ & & 9 \\
\hline$\cdot, \cdot 1$ & $* * \bullet, 70\}$ & & it \\
\hline$\cdot, \cdot 1$ & $* * \bullet, 0 \vee 7$ & & 10 \\
\hline$\cdot, \cdot 1$ & $* * \bullet, \eta r r$ & & 17 \\
\hline$\cdot, \cdot 1$ & $* * \bullet, \vee 7 \Lambda$ & \multirow{7}{*}{ التجنبــــى } & $r$ \\
\hline$\cdot, \cdot 1$ & $* * *, 0 \leqslant Y$ & & 0 \\
\hline$\cdot, \cdot 1$ & $* * *, 010$ & & 7 \\
\hline$\cdot, \cdot 1$ & $* * \bullet, 01$ & & ir \\
\hline$\cdot, \cdot 1$ & $* * \bullet$, IVr & & iv \\
\hline$\cdot, \cdot 1$ & $* * \bullet, 090$ & & 11 \\
\hline$\cdot,+1$ & $* * \bullet, Y Y \xi$ & & r. \\
\hline$\cdot, \cdot 1$ & **•, ๆ & \multirow{6}{*}{ الأمـــــن } & $\varepsilon$ \\
\hline$\cdot, \cdot 1$ & $* * \bullet, \mathfrak{Z} Y$ & & $v$ \\
\hline$\cdot, \cdot 1$ & ***, YAV & & 1. \\
\hline$\cdot, \cdot 1$ & $* *$, rA. & & 11 \\
\hline$\cdot, \cdot 1$ & $* *, 01 \mathrm{~V}$ & & $1 \varepsilon$ \\
\hline$\cdot,+1$ & $* * \bullet$, rA & & 19 \\
\hline
\end{tabular}

**." دالة عند مستوى I.,.,

ثبــــات المةقبــــاسر:

قامت الباحثة بالتحقق من ثبات الاستبانة للأبعاد والمقياس ككل وذلك باستخدام معامل

ألفا لكرو نباخ، وذلك على النحو التالي: جدول (0) معامل ألفا لكرو نباخ لحساب ثبات المقياس

\begin{tabular}{|c|c|}
\hline قيمــــة معـــامــل ألفــــا لكـــرو نبــــاخ & 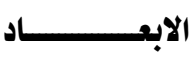 \\
\hline$\cdot, n$ & القلق \\
\hline$\cdot, v r$ & التجنبى \\
\hline$\cdot, r 1$ & 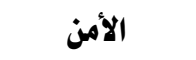 \\
\hline$\cdot, v \cdot$ & الاستبانة ككل \\
\hline
\end{tabular}

يتضح من جدول (0) أن قيمة معامل ألفا لكرو نباخ للأبعاد والمقياس مقبولة، مما يدل

ذلك على ثبات المقياس. 


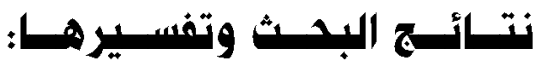

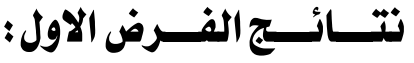

والذي ينص على "يوجد علاقة ذات دلالة احصائية بين الابتزاز العاطفي وأنماط التعلق

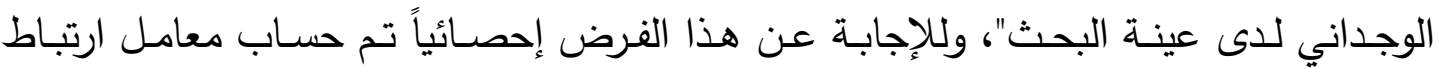

بيرسون. ويتضح ذلك في جدول (T). جلدول (7) معامل ارتباط بيرسوز بين الابتزاز العاطفي وأنماط التعلق الوجداني

\begin{tabular}{|c|c|c|}
\hline مستوى الدلالة & قيمة معامل ارتباط بيرسون مع الابتزاز الانفعالي & الأنماط \\
\hline •, ral & $\cdot, \cdot \bullet \cdot-$ & القلق \\
\hline$\cdot, 7.4$ & $\cdot,+\% 4-$ & التجنب \\
\hline$\cdot, 9 \cdot 7$ & $\therefore, \cdots \wedge$ & الأمن \\
\hline$\cdot, 49 \Lambda$ & , & مقياس أنماط التعلق الوجداني ككل \\
\hline
\end{tabular}

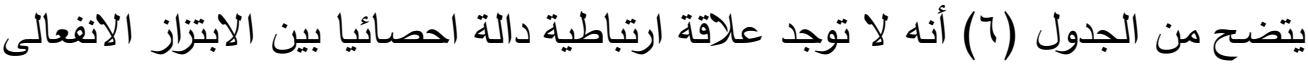

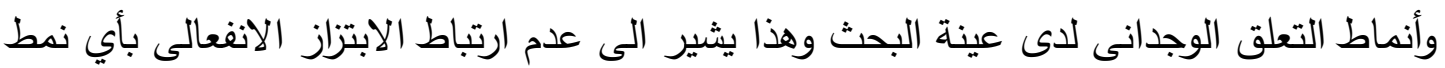

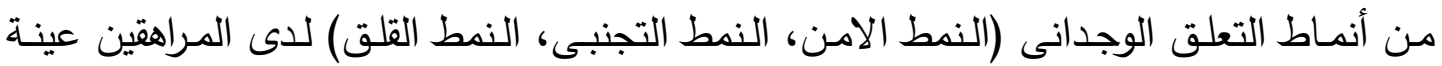

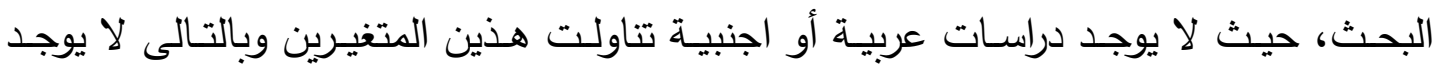
دراسات تتقق أو تختلف مع هذه النتيجة على حد علم الباحثة. ويمكن تفسير هذه النتيجة على أن الابتزاز الانفعالى يشعر المبتز بالحيرة وانعدام القوة لإهـ

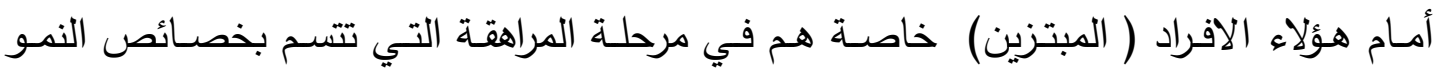

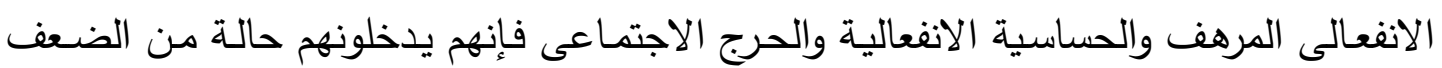

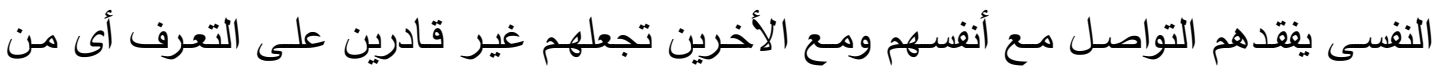

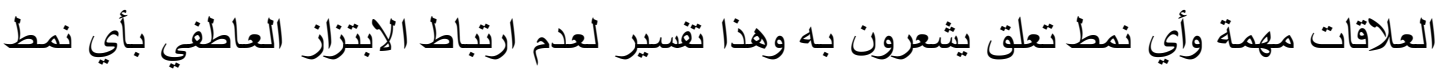
من أنماط التعلق الامن أو القلق أو التجنبى وهذا من وجهة نظون بهر الباحثة.

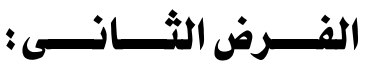

واللني ينص على "ما مستوى الابتزاز العاطفي للى عينة البحث؟"، وللإجابة عن هذا

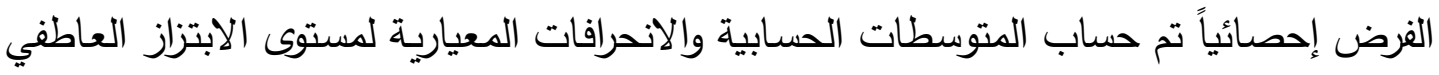
وفقا لدرجة القطع لكل بعد من الابعاد الخاصة بالمقياس كما هو موضح بالجدولئلين التالئين: 
جلول (v) توزيع للفئات وفق التلدرج المستخلم في مقياس الابتزاز الانفعالى

\begin{tabular}{|c|c|}
\hline مدى المتوسطات & درجة الانطباق \\
\hline$\varepsilon, \bullet-r, r q$ & تنطبق تماما \\
\hline$r, r o-r, 01$ & تنطبق غالبا \\
\hline$r, 0 \cdot-1, r q$ & تنطبق نادرا \\
\hline $1, \vee 0-1, \cdot \cdot$ & لا تنطبق تماماً \\
\hline
\end{tabular}

جلدول (^) المتوسطات الحسابية والانحرافات المعيارية لمستوى الابتزاز العاطفي

\begin{tabular}{|c|c|c|c|c|}
\hline الترتيب & مستوى الانطباق & الانحراف الميياري & المتوسط الحسابي & الأبعاد \\
\hline$r$ & تنطبق غالبا & $\cdot$, , Tor & r,or & الخوف \\
\hline 1 & تنطبق غالبا & •, Iro & $r, 09$ & الالزام \\
\hline \multirow[t]{2}{*}{$r$} & تنطبق غالبا & $\cdot, 7.0$ & r,o. & الشعور بالذنب \\
\hline & تنطبق غالبا & $\cdot, 7 \cdot v$ & $r, 00$ & المقياس ككل \\
\hline
\end{tabular}

يتضح من الجدول السابق أن هنالك مستوى مرتفع من الابتزاز الانفعالى وأبعاده الثلاثة بالترتيب (الالزام والخوف والشعور بالذنب) لدى عينـة البحث الذين يمثلون طلاب من المرحلة الثانوية وهذه النتيجة تتفق مع وجهة نظر فورورد (99V ( ) التي أوضحت أن الابتزاز الانفعالى مشكلة اجتماعيـة تهدد الاتفاق المشترك بين الوالدين وابنائهم بشأن الواقع والذى يحافظ على استمرار التفاعل بينهمـا، ولكى يحافظ المراهقون على هذه العلاقـة يخضـعون لمبدأ الخضـوع والاذعان لأوامرهم ويحرص الوالدان على وصول أبناءهم المرحلة الضبابية التي يمر بها عن طريق الخوف والالتزام والثعور بالذنب اذ يعملوا على اثارة هذه العوامل ليتأكدوا من أن الضحية (الابناء) سيشعرون بخوف من فقد العلاقة الاجتماعية بينهما وبالالتزام بما يراد منهم وشعور بالذنب اذ لم ينفذ ما يراد منهم. (فورورد، و99 19، 9). والابتزاز وفقا لنظرية التقاعل الرمزي سلوك متعلم من خلال عملية التتشئة الاجتماعية ولأن المبتزين العـاطفين يتصـرفون من منطلق الخوف خاصـة في مرحلة الطفولة، عندما يكونون غير قادرين على النجاة دون مسـاعدة مدن يعتـون بهم. هذا العجز يخلق ذعرا من الهجر يصساحب بعض الناس حتى بعد بلوغهم ووصولهم الى مرحلة المراهقة (Atudorei, 2011, 11). 


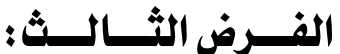

والذي ينص على "ما نمط التعلق الوجدانى الأكثر شيوعا لدى عينة البحث؟"، ولإجابة

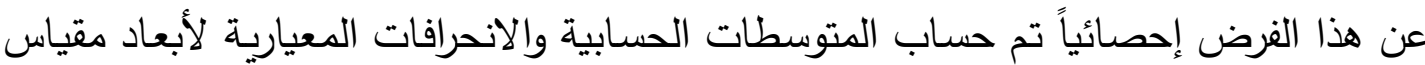
التعلق الوجدانى. ويتضح ذلك في جدول (9). جلدول (9) المتوسطات الحسابية والانحرافات المعيارية لأبعاد مقياس التعلق الوجدانى

\begin{tabular}{|c|c|c|c|c|}
\hline الـترتــيب & مستـوى الحكــــ & الانحـراف المعيـاري & المتـــوسط الحسـابــي & الأبعـاد \\
\hline$r$ & متوسط & •, 001 & $r, r \cdot$ & القلق \\
\hline 1 & متوسط & •, 091 & $r, r r$ & التجنبى \\
\hline \multirow[t]{2}{*}{$r$} & متوسط & $\cdot 0.4$ & r,1\& & الأمن \\
\hline & متوسط &., 00. & $r, r r$ & المقياس ككل \\
\hline
\end{tabular}

يتضح من الجدول (9) أن أكثر الانماط شيوعا لدى عينة البحث النمط التجنبى ويأتي في الترتيب الاول ويليه النمط القلق ثم أخيرا النمط الامن، والنمط التجنبى الذى يتميز بنظرة ايجابية نحو نفسه ونظرة سلبية مـع الاخرين وتختلف هذه النتيجة مع دراسة ابو غزال وفلوه

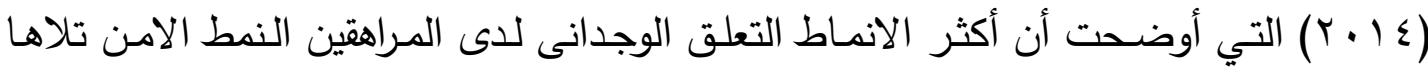

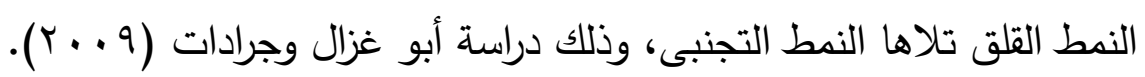

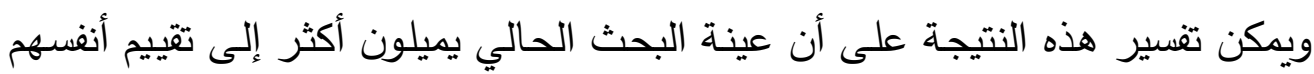
بطريقة ايجابية وتقييم الاخرين بطريقة سلبية ويمكن عزو ذلك إلى أن نسبة انتشار أنماط التعلق متشابهة في العديد من الثقافات الاجتماعية كما يبدو أن المراهقين عينة البحث النمط السائد لديهم النمط التجنبى نتيجة تعرضهم للابتزاز الانفعالى من قبل الوالدين حيث يشعرون بعدم الثقة

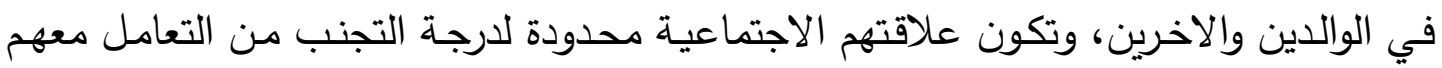
حتى لا يكون عرضة للابتزاز الانفعالى.

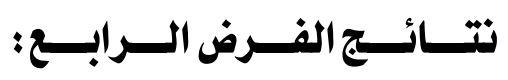

والذي ينص على "يوجد فروق ذات دلالة احصائية بين متوسطات درجات الطالبات ومتوسطات درجات الطلبة في مستوى الابتزاز العاطفي."، ولإجابة عن هذا الفرض إحصائياً تم استخدام اختبار "ت" لحساب دلالة الفروق بين المتوسطات. ويتضح ذلك في جدول (• (1). 
جدول (•1) اختبار "ت" لحساب دلالة الفروق بين متوسطات درجات الطالبات ومتوسطات درجات الطلبة في مستوى الابتزاز العاطفي

\begin{tabular}{|c|c|c|c|c|c|c|c|}
\hline مستوى الدلالة & درجة الحرية & قيمة اختبارت & الانحراف المعياري & المتوسط الحسابي & العدد العد & الجنس & الأبعاد \\
\hline \multirow{2}{*}{$\cdot, \cdot 1$} & \multirow{2}{*}{$r \cdot \Lambda$} & \multirow{2}{*}{$0, \cdot\{\wedge$} & 7,00 & rY,or & ir. & إناث إث & \multirow{2}{*}{ الخوف } \\
\hline & & & 0, vo & rr,19 & 9. & ذكور & \\
\hline \multirow{2}{*}{$\cdot, \cdot 1$} & \multirow{2}{*}{$r+1$} & \multirow{2}{*}{$\xi, r \mid}$. & 7,01 & YY, 07 & ir. & إناث & \multirow{2}{*}{ الالزام } \\
\hline & & & $7, r q$ & $r r, v \xi$ & 9. & ذ & \\
\hline \multirow{2}{*}{$\cdot, \cdot 1$} & \multirow{2}{*}{$r \cdot \Lambda$} & \multirow{2}{*}{$9, \cdot \bullet r$} & 7,11 & $r q, 91$ & ir. & إناث & \multirow{2}{*}{ بالذنب } \\
\hline & & & $\xi, \vee$ & $r r, r q$ & 9. & ذ & \\
\hline \multirow{2}{*}{ •, } & \multirow{2}{*}{$r+1$} & \multirow{2}{*}{$0,8+7$} & $11, \cdot 7$ & $A r, \bullet$ & ir. & إناث إث & \multirow{2}{*}{ ككل } \\
\hline & & & 10,71 & 79,19 & 9. & ذ & \\
\hline
\end{tabular}

يتضح من الجدول ( • () أنه توجد فروق ذات دلالة إحصائية عند مستوى (1 . . ) بين متوسطات درجات الطالبات ومتوسطات درجات الطلبة في أبعاد الابتزاز العاطفي والمقياس ككل لصـالح الطالبات ،وهذا يتفق مـع دراسـة محيى الدين ( • • ب) التي أوضـحت أن الاناث أكثر تعرضـا للابتزاز العـاطفى عن الذكور وهذا يرجـع إلى طبيعـة الانـاث وطبيعـة التتشـئة الاجتماعيـة التـي يتربـى عليهـا الانـاث مـن مقـدار القيـود المفروضــة على نشـاطات الانـاث الاجتماعيـة في المجتمـع السـودي والتزام الانـاث مـن الناحيـة الدينيـة والاخلاقيـة وانصـياعهم لأوامر الوالدين، واذ لم يقوموا بهذا يشعرون بتأنيب الضمير وبالتالى الثعور بالذنب. وهذا يفسر أن مستوى الابتزاز العاطفي بأبعاده الثلاثة عند الاناث أعلى من الذكور في المجتمع السعودي.

\section{نتــائــــج الفـرض الخــامسس :}

والـــي يـــص علــى "يوجــــــروق ذات دلالــة احصـائية بـين متوسـطات درجـات الطالبـات ومتوسـطات درجـات الطلبـة في مقيـاس انمـاط التعلـق الوجـداني"، ولإجابـة عـن

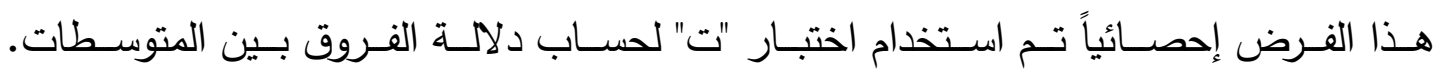
ويتضح ذلك في جدول (1).. 
د/ نعمات قاسم الابتزاز العاطفي لدى الابناء من قبل الوالدين وعلاقته بأنماط التعلقع الوجداني لدى عينة من الطلاب الهدراس الثانوية

\section{جلدول (11) اختبار ”ت" لحساب دلالة الفروق بين متوسطات درجات}

الطالبات ومتوسطات درجات الطلبة في مقياس انماط التعلق الوجلاني.

\begin{tabular}{|c|c|c|c|c|c|c|c|}
\hline مستوى الدلالة & درجة الحرية & قيمة اختبارت & الانحراف المعياري & المتوسط الحسابي & العدد & الجنس & الأبعاد \\
\hline \multirow{2}{*}{$\cdot, A r Y$} & \multirow{2}{*}{$r+1$} & \multirow{2}{*}{$\cdot, r 19$} & $r, \wedge 0$ & $r r, r r$ & ir. & إناث & \multirow{2}{*}{ القلق } \\
\hline & & & $r, 99$ & rr, $\boldsymbol{Z}$ & 9. & ذ كور & \\
\hline \multirow{2}{*}{$\cdot, 9 \leqslant 7$} & \multirow{2}{*}{$r+1$} & \multirow{2}{*}{$\cdot, \cdot 7 \gamma$} & $\xi, \bullet \vee$ & rr, ro & ir. & 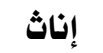 & \multirow{2}{*}{ التجنبى } \\
\hline & & & $\xi$, ro & $r r, r q$ & 9. & ذكور & \\
\hline \multirow{2}{*}{ •, $r \checkmark v$} & \multirow{2}{*}{$r+\Lambda$} & \multirow{2}{*}{$\cdot$, YAs } & $r, \cdot r$ & $1 \mathrm{~A}, \mathrm{Vq}$ & ir. & إناث & \multirow{2}{*}{ الأمن } \\
\hline & & & $r, \cdot \cdot$ & $\| \Lambda, \wedge \Lambda$ & 9. & ذكور & \\
\hline \multirow{2}{*}{ - VYA } & \multirow{2}{*}{$r+1$} & \multirow{2}{*}{$\bullet, r \leqslant \wedge$} & 0,07 & $7 \xi, r \mu$ & ir. & إناث & \multirow{2}{*}{ ككل المياس } \\
\hline & & & $0,9 \xi$ & ז T\&, & 9. & ذكور & \\
\hline
\end{tabular}

يتضح من الجدول (1 (1) أنه لا توجد فروق ذات دلالة إحصائية بين متوسطات درجات

الطالبات ومتوسطات درجات الطلبة في أبعاد مقياس أنماط التعلق الوجداني والمقياس ككل وهذا يعنى عدم دلالة الجنس في أنماط التعلق الوجدانى، وهذه النتيجة تختلف مع دراسـة أبو غزال وفلوه (ع ( • r) التي أوضحت أن هنالك فروق دالة احصـائيا تعزى لمتغير النوع في نمط التعلق التجنبى لصـالح الاناث، وفى نمط التعلق التجنبى لصالح الذكور ، بينما لا يوجد فروق دالة إحصائيا في نمط التعلق الأمن وترجع الباحثة تفسير عدم دلالة الجنس إلى أن نمو رابطة التعلق ترتبط بالعلاقة الوجدانية والتفاعل الايجابى نحو الابناء بعيدا عن الجنس فإذا ما وجدت هذه الرابطة منذ الصنغر تصبح بمثابة قاعدة امن توفر الراحة والأمن للابن ينطلق ليكتثف إمكاناته وطاقاته والعالم المحيط به.

\section{نتــائســـج الفــرض الســادس :}

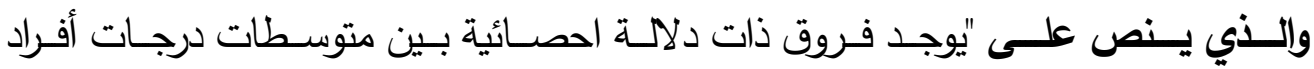

العينـة فـي مسـتوى الابتـزاز العـاطفي وفقــا لمتغيـر المسـتوى التعليمـي للوالــين."، وللإجابـة عـنـ

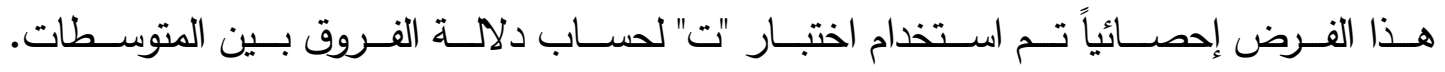
ويتضح ذلك في جدول (Y I). 
جدول (r ا ) اختبار ”ت" لحساب دلالة الفروق بين متوسطات درجات

أفراد العينة في مستوى الابتزاز العاطفي وفقا لمتفير المستوى التعليمي

\begin{tabular}{|c|c|c|c|c|c|c|c|}
\hline مستوى الدلالة| & درجة الحرية & قيمة اختبارت & الانحراف المعياري & المتوسط الحسابي & العدد العد & المستوى التعليمي & الأبعاد \\
\hline \multirow{2}{*}{$\cdot, \cdot 1$} & \multirow{2}{*}{$r \cdot 1$} & \multirow{2}{*}{ r,AOr } & $0, \mathrm{YA}$ & $r r, q r$ & 1.4 & الجامعي & \multirow{2}{*}{ الخوف } \\
\hline & & & 7,19 & rV, rr & $1 \cdot v$ & دوز الجامعي & \\
\hline \multirow{2}{*}{$\bullet, \cdot 1$} & \multirow{2}{*}{$r \cdot 1$} & \multirow{2}{*}{ r,VHY } & $9, \cdot 9$ & $r \xi, r_{\bullet}$ & $1 . r$ & الجامعي & \multirow{2}{*}{ الالزام } \\
\hline & & & 7,94 & $r \vee, O \Lambda$ & $1 \cdot v$ & دون الجامعي & \\
\hline \multirow{2}{*}{$\cdot, \cdot 1$} & \multirow{2}{*}{$r \cdot \Lambda$} & \multirow{2}{*}{$0,1+4$} & $\xi, \vee \wedge$ & $r r, q$. & $1 . r$ & الجامعي & \multirow{2}{*}{ السالذنب } \\
\hline & & & 9,89 & 17,90 & $1 \cdot v$ & دون الجامعي & \\
\hline \multirow{2}{*}{$\cdot, \cdot 1$} & \multirow{2}{*}{$r+1$} & \multirow{2}{*}{,$\{94$} & 10,19 & $v 1, \cdot \varepsilon$ & 1.4 & الجامعي & \multirow{2}{*}{ ككل } \\
\hline & & & $19, Y 1$ & $\wedge 1, \wedge 0$ & $1 \cdot v$ & دوز الجامعي & \\
\hline
\end{tabular}

يتضح من الجدول (Y Y) أنه توجد فروق ذات دلالة إحصائية عند مستوى (1 +, •) بين

متوسطات درجات أفراد العينة في أبعاد الابتزاز العاطفي والمقياس ككل وفقا لمتغير المستوى التعليمي للوالدين لصالح دون الجامعي، وهذا يعنى أن المستوى التعليمي للوالدين له أثر إيجابي في عدم استخدام اشكال الاساءة الانفعالية مثل الابتزاز الانفعالى وتتفق هذه النتيجة مـع دراسة سـالم (Y . . r) التي أوضـحت ان هنـاك علاقـة طرديـة موجبـة بـين أسـاليب المعاملـة الوالديـة السوية التي تساعد على اقامـة علاقات سوية بين الوالدين والابناء والمستوى التعليمي للوالدين ،بمعنى كلما زاد المستوى التعليمي للوالدين يؤثر تأثيرا ايجابيا على عدم استخدام الاساليب الغير السوية وأثكال الاساءة الانفعالية ومنها الابتزاز الانفعالى، وتختلف هذه النتيجة مع دراسة عبد المجيد، حسن (10 ـ ( التي أوضـحت أنـه لا يوجد فروق دالـة احصـائيا لأسـاليب المعاملـة الوالدية ومنها الاساءة الانفعالية تعزى إلى المستوى التعليمي للوالدين.

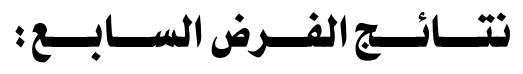

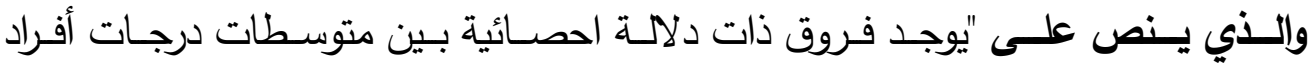

العينـة فـي مقيـاس أنمـاط التعلـق الوجـداني وفقـا لمتغيـر المسـتوى التعليــي"، ولإجابـة عـن

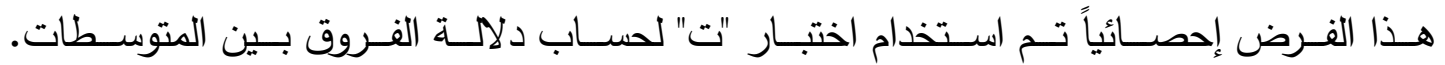
ويتضح ذلك في جدول (T) ). 
د/ نعمات قاسم الابتزاز العاطفي لدى الابناء من قبل الوالدين وعلاقته بأنماط التعلقع الوجداني لدى عينة من الطلاب الهدراس الثانوية

\begin{tabular}{|c|c|c|c|c|c|c|c|}
\hline & جات & تثتوسر المستوك & ملق ابلابلة الوجداثي وقة & 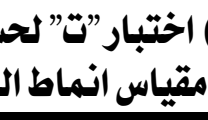 & ينة في & أفراد ا & \\
\hline مستوى الدلالة & درجة الحرية & قيمة اختبارت & الانحراف المعياري & المتوسط الحسابي & العلد & المستوى التمليمي & الأبعاد \\
\hline \multirow{2}{*}{-, โด४ } & \multirow{2}{*}{$r+\Lambda$} & \multirow{2}{*}{$\bullet, 7 \wedge$ • } & $\varepsilon, \uparrow$ & $r Y, O Y$ & $1 . r$ & الجامعي & \multirow{2}{*}{ القلق } \\
\hline & & & $r, Y q$ & $r r, r \cdot$ & $1 \cdot v$ & دوز الجامعي & \\
\hline \multirow{2}{*}{$\cdot, \mathrm{HI}$} & \multirow{2}{*}{$r \cdot \Lambda$} & \multirow{2}{*}{$1, \cdot 19$} & $\xi, \mathfrak{\xi \xi}$ & Yr, 07 & $1 . r$ & الجامعي & \multirow{2}{*}{ لتجنبى } \\
\hline & & & $r, \Lambda T$ & $r r, 9 \Lambda$ & $1 \cdot v$ & دوز الجامعي & \\
\hline \multirow{2}{*}{ •, HYA } & \multirow{2}{*}{$r \cdot \Lambda$} & \multirow{2}{*}{$\bullet, 911$} & $r, 99$ & $1 \Lambda, 7$. & $1 . r$ & الجامعي & \multirow{2}{*}{ الامن } \\
\hline & & & $r, \cdot r$ & $19, \cdots$ & $1 \cdot v$ & دوز الجامعي & \\
\hline \multirow{2}{*}{ •, \А૬ } & \multirow{2}{*}{$r+1$} & \multirow{2}{*}{$\cdot, 7 \wedge 0$} & 7,19 & $7 \varepsilon, V$ & $1 \cdot r$ & الجامعي & \multirow{2}{*}{ ككل } \\
\hline & & & $0, r r$ & 78,19 & $1 \cdot V$ & دوز الجامعي & \\
\hline
\end{tabular}

يتضح من الجدول (س ا) أنه لا توجد فروق ذات دلالة إحصائية بين متوسطات درجات أفراد العينـة في أبعـاد مقيـاس انمـاط التعلق الوجداني والمقيـاس ككل وفقـا لمتغيـر المستوى التعليمي، وهذا يعنى عدم دلالة المستوى التعليمي للوالدين في انماط التعلق الوجدانى لدى عينـة البحث، ويمكن تفسير هذه النتيجة أن أنماط التعلق الوجدانى الامن أو الغير الامن يتأثر بالدور التربوي للوالدين في تكوين الابناء تكوينا اجتماعيا سواء أكانوا من مستويات تعليمية مختلفة ولكن يكون التركيز على النظام الاسرى والعدالة الوالدية بين الابناء والعلاقات الاجتماعية مع

$$
\text { الاخرين. (حلاوة، 11 (9)، (9). }
$$

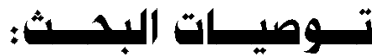

التواصـل المباشـر بين الوالدين والادارة المدرسية خاصــة عند وجـود مشكلات نفسية واجتماعية للأبناء للتدخل المبكر لعدم تفاقم المشكلات. اعداد برامج ارشـادية للوالدين للتعرف على مدى تأثير الابتزاز الانفعالى على سمات الشخصية لاى أبنائهم. الاهتمـام بمرحلـة المراهقـة واعداد مراكـز للاستثــارة النفسية فـى المــارس المتوســة والثانوية تحت إشراف كليات التربية ومراكز التوجيه والارشاد النفسى. تصميم برامج ارشادية للوالدين للتعرف على أنماط التعلق الوجدانى والانماط الأمنه التي توطد العلاقة الوالدين بينهم وبين أبنائهم لكى يعيشوا حياه اسرية سوية. ضرورة تصميم برامج تدريبية تستهدف الارتقاء أو تتمية تقدير الذات لدى الطلبة ذوي نمط التعلق القلق والتجنبي. 


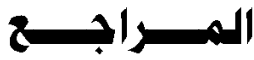

\section{المــراجـــم العــربيـــة:}

- أبو راسين، محمد بن حسن. (10 · ب).أ نماط التعلق في علاقتها بكل من الذكاء الوجداني والإبداع

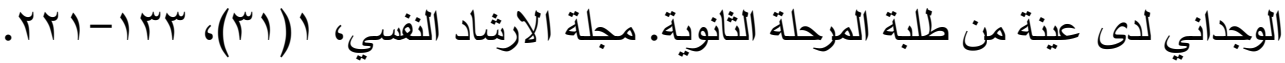

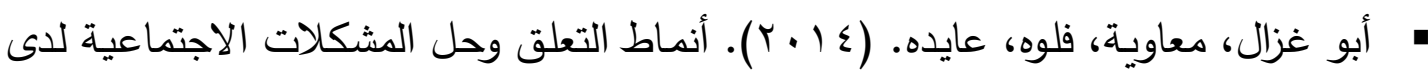
الطلبة المراهفين وفقا لمتغيري النوع الاجتماعى والفئة العمرية. المجلة الاردنية في العلوم

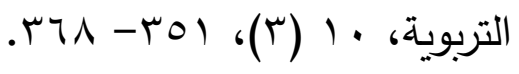

" أبو غزال، معاوية وجردات، عبد الكريم. (9 . . r). أنماط تعلق الراثدين وعلاقتها بتقدير

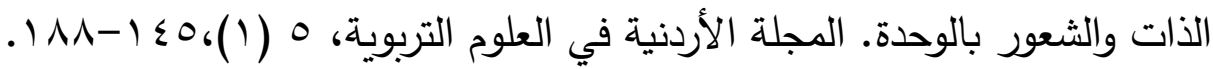

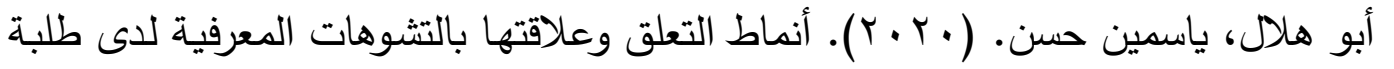

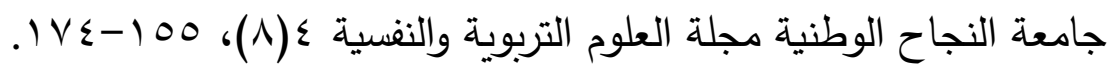

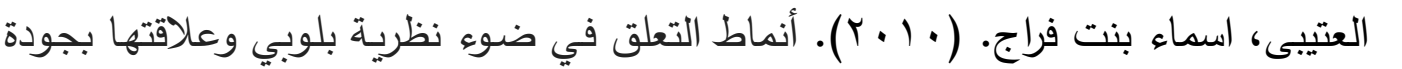
الحياة لاى طالبات المرحلة الثانوية بمدينة الرياض رساله الدكتوراه، جامعة الملك سعود.

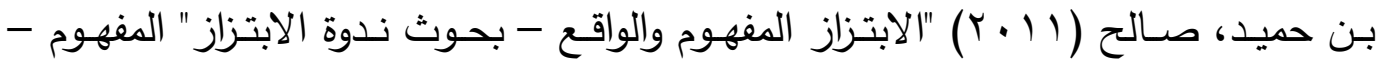
الاسباب -العلاج. الرياض. مكتبة الملك فهر الوطنية. • حلاوة، باسمة (1) (Y). دور الوالدين في تكوين الثخصية الاجتماعية عند الأبناء "دراسة

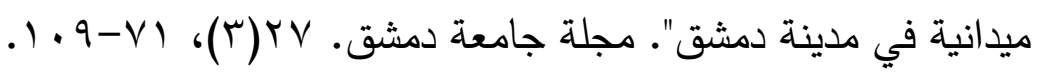

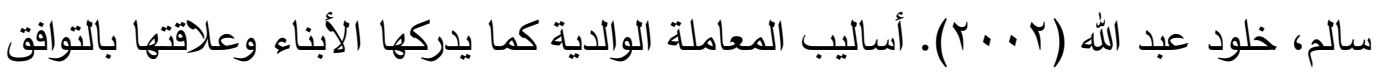
النفسى لدى طلاب الصف السابع والثامن .رسالة ماجستير، جامعة أم درمان.

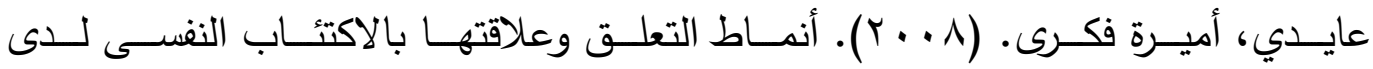
المراهقين(دراسة سيكو مترية- كلينيكيه). رسالة الماجستير ، كلية التربية، جامعة طنطا.

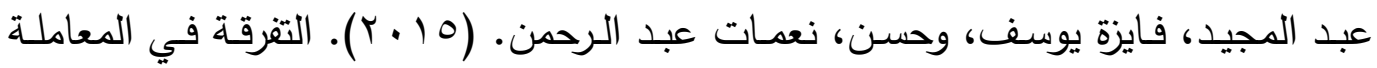
الوالدية كما يدركها الأبناء وعلاقتها ببعض المشكلات السلوكية لاى عينة من الاطفال من

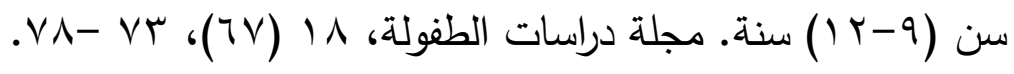


فورود، سوزان، فرايز ، دونا. (0 ( ب). الابتزاز العاطفي: حينما يستخدم من حولك الخوف

والالزام والشعور بالذنب للتلاعب بك. الرياض. مكتبة جرير .

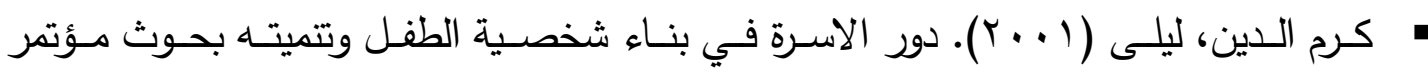
عـين شـمس بعنـوان (دور تربيـة الطفـل في الاصــلاح الحضــاري) القـاهرة مـن الفترة VY9ץ يوليو، 11. (1) كفاقي، علاء الدين (T . . ب). موسوعة علم النفس التأهيلي - الجزء الاول - القاهرة - دار الفكر العربي.

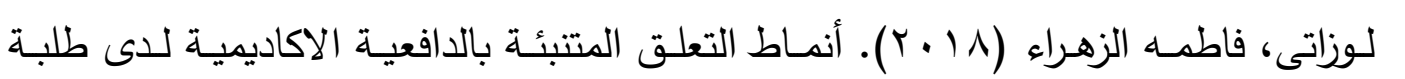

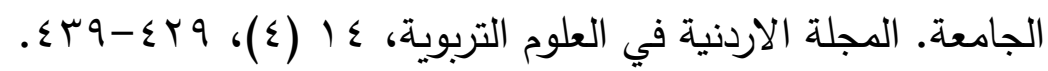
هحمد، هبه محمود (T ( • Y). سمات الشخصية كمتغيرات وسيطة في العلاقة بين الابتزاز العـاطفي أعـراض اضـراب الثخصـية الحديـة لدى عينـة غير اكلينيكية مـن المتزوجين،

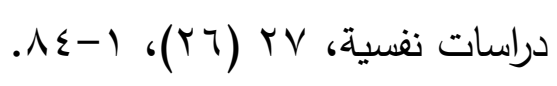

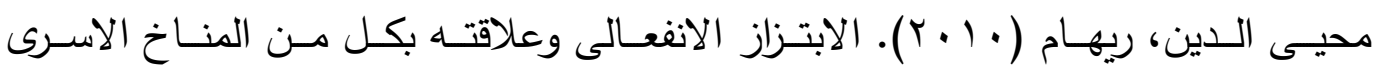
والعمليـات الاسـرية وبعـض متغيـرات الثخصـية لـدى طالبـات المرحلـة الثانويـة: دراســة سـيكو متريـة كلينيكييـه. رسـالة دكتـوراه، جامعـة القـاهرة، معهد الدراسـات التربويـة، قسم الارشاد النغسى.

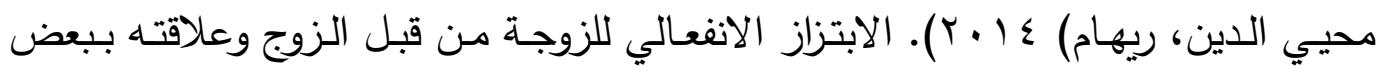
متغيرات شخصية الزوجة مجلة دراسات عربية، سا (Y)، VTr-1)

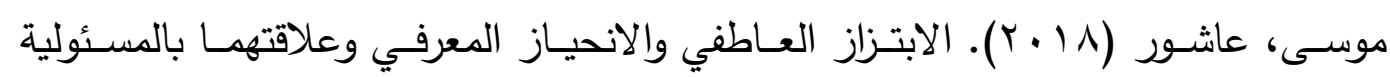
الشخصية لدى المعلمين. رسالة دكتوراه، جامعة بغداد، كلية التربية. هادى، أنوار (r ( • ( ). الابتزاز الانفعالى بين الزوجين، مجلة الاستاذ، كلية بن رشد للعلوم

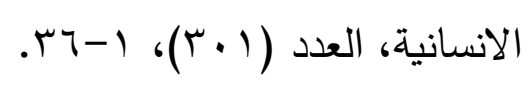

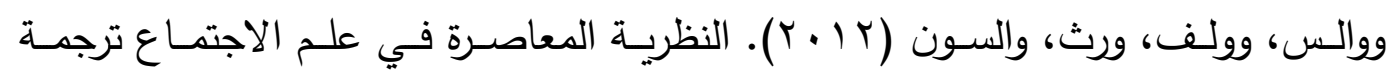
الحوراني، محمد عبد الكريم. دار مجدلاوي للنشر والتوزيع. عمان. الاردن. 


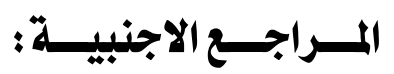

- Atudorie. I. (2011). Perceptive differences on domestic violence against women. Bulletin of the Transilvania. 4 (53), 87- 93.

- Benjamin, J. \& Virginia, k, (2004). Synopsis of Psychiatry, Behavioral Sicence. Clinical Psychiatry.

- Bartholmew, K \& Horowitze, L(1991). Attachment styles among young adults: A test of four category model, Journal of personality and social psychology. 161. pp 226- 244.

- Bruce, p, (2006) Bonding and Attachment in Maltreated children, PhD Texas University. AAT 509.

- Chen, Sh. (2009). Types of customer emotional blackmail perceived by frontline service employees. Social Behavior and Personality. 37 (7), 895- 904.

- Chen, Sh. (2010). Relations of Machiavellianism with emotional orientation of salespeople. Procardia Social and Behavioral sciences, 5, 294- 303.

- Chu Liu, Ch. (2010). The relationship between Empylees Perception of Emotional Blackmail and their Well-Being . Procardia Social and Behavioral Sciences, 5, 299- 303.

- Jennifer N, Donna, F, and Horbury, A. (2001): The Effect of Parenting Styles and Childhood Attachment Patterns on Intimate Relationships, Journal of Instructional Psychology , 1 (7), pp 127-145.

- Lafreniere, P. (2000). Emotional development: a Biosocial Perspective. Belm ont, London: Wadsworth. Press. 
د/ نعمات قاسم الابتزاز العاطفيي لوى الابناء من قبل الوالدين وعلاقته بأنماط التعلة الوجداني لوى عينة من الطلاب المدراس الثانوية

- Laung, A. (2005). Emotional Intelligence or. Emotional Blackmail a Study of Chinese Professional -Services Firm International Journal of Cross Culture Management. 5 (2). 181 - 196.

- Şirin, H. (2017). The Predictive Power of Adult Attachment Patterns on Interpersonal Cognitive Distortions of University Students. Educational Research and Reviews Seljuk University, 12(18). 127-156. 